University of Rhode Island

DigitalCommons@URI

Open Access Master's Theses

1970

\title{
Tamerlane to Eureka: The Evolution of Poe's Cosmic Myth
}

Francis E. Antosca

University of Rhode Island

Follow this and additional works at: https://digitalcommons.uri.edu/theses

Recommended Citation

Antosca, Francis E., "Tamerlane to Eureka: The Evolution of Poe's Cosmic Myth" (1970). Open Access

Master's Theses. Paper 1364.

https://digitalcommons.uri.edu/theses/1364

This Thesis is brought to you for free and open access by DigitalCommons@URI. It has been accepted for inclusion in Open Access Master's Theses by an authorized administrator of DigitalCommons@URI. For more information, please contact digitalcommons-group@uri.edu. 
TAMERLANE TO EUREKA: THE EVOLUTION

OF POE'S COSMIC MYTH

BY

FRANCIS E. ANTOSGA

A THESIS SUBMITTED IN PARTIAL FULFILLMENT

OF THE REQUIREMENTS

FOR THE DEGREE OF

MASTER OF ARTS

IN

ENGLISH

UNI VERSITY OF RHODE ISLAND

1970 
MASTER OF ARTS THESIS

OF

FRANCIS E. ANTOSCA

Approved :

Thesis Committee:

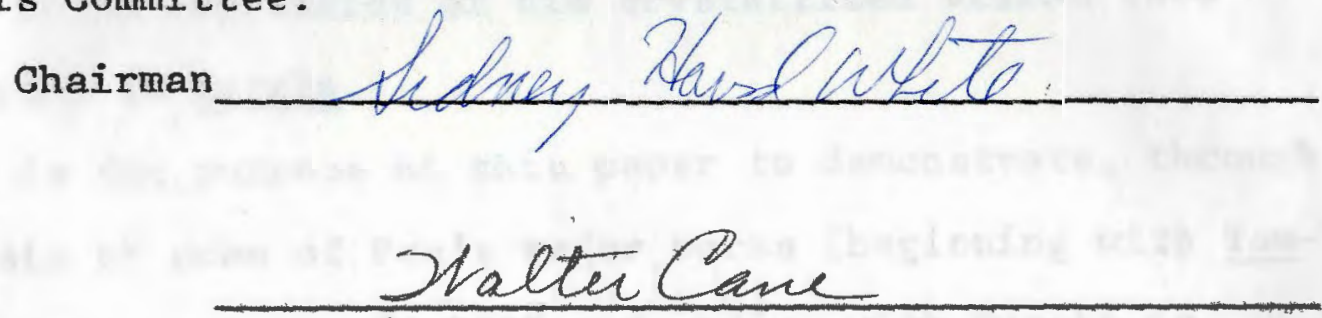

6. Perthur Pobenion

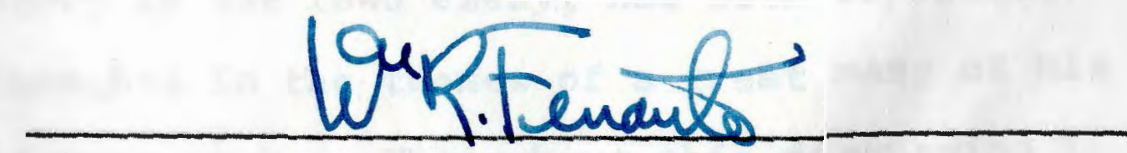

UNI VERSITY OF RHODE ISLAND 


\section{THESIS ABSTRACT}

Near the end of his life, in the summer of 1848, Edgar Allan Poe published what he chose to call a "prose poem," but which, in fact, was a lengthy and complex scientific essay, titled Eureka. In that work he attempted to explain, both imaginatively and scientifically, the origin, nature, and destiny of man and his universe; a subject about which he had speculated for many years. The many fragments of Poe's total vision are recognizable throughout his poetry, essays, letters and tales. When viewed chronologically and thematically, they appear to constitute an evolutionary process that resulted in an expression of his crystallized vision (his Cosmic Myth) in Eureka.

It is the purpose of this paper to demonstrate, through an analysis of some of Poe's major works (beginning with Tamerlane and Other Poems in 1827 and ending with Eureka in 1848) that his myth of the cosmos artistically evolved over that period of time and that the major concepts, presented as a complete theory in the 1848 essay, had been expressed as fragmentary thoughts in the themes of a great many of his earlier, more literary works. Throughout this discussion I have also drawn considerable information from numerous nineteenth and twentieth century Poe biographers and critics. 
I believe that this paper has successfully demonstrated that the foundations of Poe's Cosmic Myth are recognizable in an embryonic form as early as 1827, in his first published work, Tamerlane and Other Poems; and that the evolution of his ultimate vision, expressed in Eureka in 1848, is traceable through the developing themes of his major works during that period. 
CONTENTS

PREFACE

I. "TAMERLANE," "AL AARAAF" AND EARLY POEMS:

THE DAWN OF VISION . . . . . . . . . . .

II. EARLY TALES: THE MAELSTROM EXPLORED . . . . . 26

III. ARTHUR GORDON PYM AND THE JOURNEY TO COSMIC CONSCIOUSNESS. . . . . . . . . 47

IV. LATER TALES: CONVERSATION, COLLOQUY, AND COLIAPSE ............... 70

V. EUREKA: THE DREAMER'S BOOK OF TRUTHS . . . . . 93 BIBLIOGRAPHY . . . . . . . . . . . . 107 


\section{PREFACE}

In a letter to Nathaniel P. Willis dated January 22, 1848, Edgar Allan Poe briefly explained his plans for what he saw as an attempt to re-establish himself in the literary world:

My general aim is to start a Magazine, to be called "The Stylus;" but it would be useless to me, even when established, if not entirely out of the control of a publisher. I mean, therefore, to get up a Journal which shall be my own, at all points.... In order to get the means of taking the first step, I propose to lecture at the Society Library, on Thursday, the 3d of February--and, that there may be no cause of squabbling, my subject shall not be literary at all. I have chosen a broad text--"The Universe."I

Poe"s "broad text--"The Universe" was contained in that February lecture at New York under the title of Eureka, and, since he believed most of the subsequent reviews of his presentation to be somewhat less than accurate, he attempted in several later letters to clarify his concepts. ${ }^{2}$ On February 29,1848 , in one such letter to George W. Eveleth, Poe

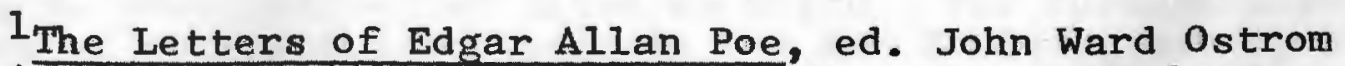
(Cambridge, Mass., 1948) II, p. 359. Hereafter cited as Ostrom I or II.

${ }^{2}$ For later correspondence in which Poe attempted to c.larify Eureka, see Ostrom II, pp. 360-365. 
included an abstract of Eureka, which A. H. Quinn views as

his "most inclusive explanation": 3

The General Proposition is this:--Because Nothing was, therefore All Things are.

1--An inspection of the universality of Gravitation--i.e., of the fact that each particle tends, not to any one common point, but to every other particle-suggests perfect totality, or absolute unity, as the source of the phenomenon.

2--Gravity is but the mode in which is manifested the tendency of all things to return into their original unity; is but the reaction of the first Divine Act.

3--The law regulating the return--i.e., the law of Gravitation is but a necessary result of irradiation of matter through space:-- this equable irradiation is necessary as a basis for the Nebular Theory of Laplace.

4--The Universe of Stars (contradistinguished from the Universe of Space) is Iimited.

5--Mind is cognizant of Matter only through its two properties, attraction and repulsion: therefore Matter is only attraction \& repulsion:...

6--Matter, springing from Unity, sprang from Nothingness:- $-i . e$. , was created.

7--All will return to Nothingness, in returning to Unity.... What I have propounded will (in good time) revolutionize the world of Physical \& Metaphysical Science. I say this calmly--but I say it. ${ }^{4}$

Although Poe was mistaken in his stated belief that Eureka would "revolutionize" science, the concepts contained in that lecture were, nonetheless, very complex and not with-

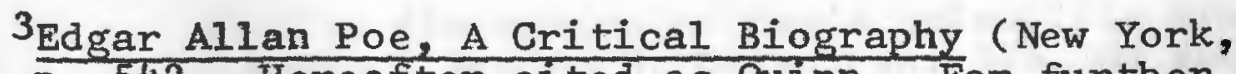
1949), p. 542. Hereafter cited as Quinn. For further discussion of correspondence between Poe and Eveleth, see T. 0. Mabbot, "The Letters from George W. Eveleth to Edgar Allan Poe," Bulletin of New York Public Library, XXVI (1922), 171195; and James S. Wilson, "The Letters of Edgar Allan Poe to George W. Eveleth, "Alumni Bulletin, University of Virginia, XVII (January, 1924), 34-39.

${ }^{4}$ Ostrom, Vol. II, pp. 361-362. 
out some basis in scientific discoveries up to that time. 5 However, Eureka is not simply a scientific treatise. It is a fusion of many years of scientific investigation and artistic fantasy, in effect--the ultimate expression of Poe's unique Cosmic Myth.

By Cosmic Myth I mean Poe's final conclusions on the cyclic nature of the universe and the relationship of man to God in that cycle, as viewed through the poet's individual combination of reason and intuition. Eric Carlson writes that if Poe's work, "to be adequately understood,... needs to be read entire, a central place must be given to the poems, tales, and essays that develop his cosmic myth." ${ }^{6}$ Although the detailed explanation of his vision of the universe did not come until 1848, Poe identified the theory which formed the basis for his view of the universe as early as 1841, in his review of Macaulay's Gritical and Miscellaneous Essays: "The only irrefutable argument in support of the soul's immortality--or, rather, the only conclusive proof of man's alternate dissolution and rejuvenescence ad infinitum--is to be found in analogies deduced from the modern established

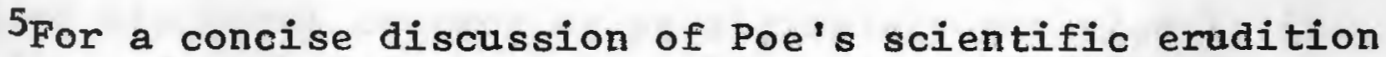
as evidence in Eureka, see A. H. Quinn, pp. 545-566 and Alfred Russell Wallace, Edgar Allan Poe (New York, n.d.): The latter volume contains "17 Letters of Poe's Scientific Erudition in Eureka."

"Introduction," Introduction to Poe, A Thematic Reader (Glenview, Ilinois, 1967), p. xxili. Hereafter cited as Carlson. 
theory of the nebular cosmogony." 7 In a note to that review, Poe elaborated on this theory: "This cosmogony demonstrates that all existing bodies in the universe are formed of a nebular matter, a rare ethereal medium, pervading space-shows the mode and laws of formation--and proves that all things are in a perpetual state of progress--that nothing in nature is perfected" (X, p. 160).

The foundations of Poe's myth of the cosmos are recognizable in an embryonic form as early as 1827, in his first published work, Tamerlane and Other Poems, and it appears likely that from that time to the publishing of Eureka in 1848, Poe spent a great deal of time considering the complex existence of man and his place in the universe. It is with Poe's considerations of man's existence, as evidenced in his poetry, letters, essays, and tales, that this paper is concerned; and, through an analysis of some of those major works from 1827 to 1848 , I believe it is possible that the evolution of his theories can be understood.

It is important to note that the several aspects of Poe's final theories were treated in many different ways and to many different degrees, resulting in a fragmentary revelation of his total concept as he ultimately revealed it in

7 The Complete Works of Edgar Allan Poe, ed. James A. Harrison (New York, 1965) X, p. 160 . Unless otherwise indicated, all quotations from Poe's works hereafter will be from this collection. Volume and page numbers will be indicated parenthetically in the text. 
Eureka. In his poetry and tales I believe can be found the questioning of the meaning of reality, an exploration of the world of dreams, and the belief in illusion as the only reality. Also, in Poe's poetry I see revealed his unwillingness to believe that any being could be superior to himself, a view which apparently became part of his vision in tureka in which all matter seems eventually to return to its original form as the single primordial particle constituting the essence of God. In his essays and tales, he indicated his belief in the importance of intuition as a method of arriving at truth and the superiority of this method over deductive and inductive reasoning when used alone. Finally, in Poe's essays and tales can be found the repeated theme of sudden catastrophic collapse of individuals, families, and the world of man, a theme which can be viewed as a microcosmic treatment of the catastrophic destruction of the universe, a central part of the concepts expressed in Eureka.

At least in part, this chronological study of selected major works of Edgar Allan Poe will be an attempt to lead to an awareness of, as Patrick Quinn writes, "an imaginative exploration beyond the frontiers of conscious knowledge." 8 Also, as Quinn says further:

And Poe's unique ability as a writer consists in this: that when we read his stories with an awareness of what his ambitious intention was, we too may in some degree

8The French Face of Edgar Allan Poe (Carbondale, (1957), p. 274 . 
take part in this imaginative exploration. Through the spectrum of his stories the experience we have of the actual world, and the assumptions we make regarding it, come through in strange colors and fall into patterns that may have existed before for us, but only in those dreams that cannot be remembered. Poe well knew the everyday world would call his visions fantastic, and so for most of his readers they seem to be. But so deep was Poe's apprehension of them that they took on for him the character of profound truths, grasped by the intuition rather than the intelligence, "upon the verge of the great secret." To read Poe properly we should realize that the experience which his stories uniquely offer us is that of participating in the life of a great ontological imagination. It is an experience of exploration and discovery that is offered us, a voyage of the mind.9

It is the principal purpose of this paper to trace that voyage of Poe's mind, from the 1827 publication of Tamerlane and Other Poems to the 1848 publication of Eureka, specifically as that mind struggled with the complexities of existence and ultimately arrived at the private vision of its own Cosmic Myth. 


\section{I. "TAMERLANE," "AL AARAAF" AND TARLY POEMS: THE DAWN OF VISION}

Edgar Allan Poe's determined and unending quest for an awareness of the purpose of man's existence and the relationship of the human condition to the universal matter began with a little volume of poetry, of which less than fifty not very successful copies were printed at the young poet's own expense. ${ }^{1}$ Tamerlane and Other Poems, first published in Boston sometime during the summer of 1827 , did not bring the lonely Poe any amount of fame, nor did it net the somewhat impoverished, struggling artist any financial profit. Considered from this practical, but rather limited point of view, one can conclude only that Poe's first attempt to enter the literary world ended in a relatively unnoticed failure, due to a lack of recognition, rather than the absence of poetic genius.

However, Poe's first volume of poetry ultimately takes on immense importance and significance when viewed as an integral part of the total picture of his literary achievements, particularly as those achievements are seen as expres-

$1_{\text {T. }} 0$. Mabbot speculates that, due to the relatively low selling price of the book ( $12 \frac{1}{2} \zeta$ ) and the usually anticipated printer's profit, around 200 copies were actually printed. "Introduction," Tamerlane and Other Poems (New York, 1941), p. xxx. 
sions of the poet's concern for and growing awareness of the meaning of life and man's place in the cosmos. Examined from this point of view, it becomes increasingly apparent that the poetic themes expressed in Tamerlane and Other Poems carry with them the importance of being the first published indication of the direction in which Poe's probing and questioning mind would take him, as he explored the complex existence of the physical and spiritual universe in this and later works.

There are several theories as to the origin of Poe's first volume of poems. Martin S. Shockley suggests the poet's possible exposure to M. Lewis's play, Timour the Tartar, presented in Richmond in July and October of 1822, could have influenced Poe's writing of the title poem. ${ }^{2}$ However, Hervey Allan writes that Tamerlane and Other Poems "first began to take shape" while he was at the University of Virginia, ${ }^{3}$ and Killis Campbell agrees that "it is barely possible that the poem ("Tamerlane") may have been originally conceived as early as $1821-1822, "$ considering unlikely the possibility that it was written before $1826 .^{4}$ Although opinions vary amongst scholars on any specific sources of Poe's first published poems, there is general agreement that

2"Timour the Tartar' and Poe's 'Tamerlane'" PMLA, LIX (December, 1941), 1103-1106.

${ }^{3}$ I srafel, The Life and Times of Edgar Allan Poe (New York, 1934), p. 141 .

4he Poems of Edgar Allan Poe (Boston, 1917), p. 147. 
the poet was greatly influenced by several nineteenth century romantic poets, particularly Byron. 5

Arthur H. Quinn writes that in the title poem of the collection, "Tamerlane," can be found the poet's earliest known treatment of four themes which he developed in various forms through his literary career: love, beauty, pride and death. 6 Quinn sees an awareness of these themes in "Tamerlane" as centrally important in understanding Poe's lifelong thinking "in terms of a spiritual passion that transcended human limits."7 He says further:

The...theme... of pride, strikes at once a note of conflict with earlier happiness and is coupled with regret.... The struggle to preserve spiritual integrity, which we shall have constantly to study in Poe's poetry and prose, is a consequence of a proper pride, and is here emphasized in his first poem of importance.

The themes of beauty and of love are naturally introduced together, in verses whose harmony clothes a figure of speech veracious and striking.... The final theme, death, approaches as the conqueror of love, of beauty, and of pride. 8

It is almost unnecessary to say that death as a theme is characteristic of a large majority of Poe's works. But

5For discussions of the English romantic influence on Poe, see Floyd Stoval, "Poe's Debt to Coleridge," University t Texas Studies in English, X (1930), 70-127; Kiliis CampIII, "Poe's Indebtedness to Byron," Nation, LXXXVIII (1909), 248-249; H. T. Baker, "Coleridge"s Influence on Poe's Poetry," Modern Language Notes, XXV (1910), 94-95; and Margaret Alterton, Origins of Poe's Critical Theory (New York, 1965-First published in 1925), pp. 7-45.

$$
\begin{aligned}
& { }^{6} \text { Quinn, p. } 125 . \\
& { }^{7} \text { Ibid., p. } 123 . \\
& { }^{8} \text { Ibid., pp. 122-124. }
\end{aligned}
$$


to add that its use is purely morbid and grotesque, as it is largely interpreted, would be superficial and grossly misleading. As it is treated in "Tamerlane," death, or simply the contemplation of $i t$, provides the medium through which the soul can transcend physical limitations to a realm conceived in poetic dreams. Frances Winwar says of Poe's early visionary world:

Whether in the tale of Tamerlane...or in the short poems, it is the personality of the writer that comes through, at times with disturbing clarity.....As a man he portrays himself proud, beauty-loving, independent.... For him what shelley called Intellectual Beauty becomes integrity of soul, and beauty itself a secret delight to be brooded upon until, transformed by the quality of his imagination, it finds its place in that visionary world that was his true home.9

The young Poe was a dreamer in search of beauty. However, his childhood and subsequent life with the Allans afforded him little chance to experience the kind of beauty necessary to satisfy his finely tuned sensitivity and naturally poetic instincts. The directions in which he was forced by outside pressures, particularly those of John Allan, were usually contrary to his nature and resulted in an inner turmoil which eventually forced him further away from reality and deeper into his world of dreams. ${ }^{10}$ It was in that state, and apparently only in that state, that Poe was able to sat-

\footnotetext{
9 The Haunted Palace, A Life of Edgar Allan Poe (New York, 1959), pp. 95-96.

${ }^{10}$ Although there are many excellent discussions of Poe's uhappy relationship with John Allan, including Winwar, pp. 89-149, and A. H. Quinn, Pp. 109-117, the best source of information is the correspondence in ostrom, I, pP. 4-50.
} 
isfy his hunger for beauty. ${ }^{11}$ What he was not able to find in the material world around him, he created in his visions. His innate pride and continued reveries gave rise to concepts which allowed him a sense of dignity, less in the world of men than in the realm of the spirit. Out of these visions evolved his belief in the dignity of the soul and the ultimate union of all souls in God. 12

\section{${ }^{11}$ George $\mathbf{E}$. Woodberry writes of the relationship of} beauty and imagination in Poe: "The sight of beauty did not affect his aesthetic sense so much as it aroused his dreaming faculty...his imagination so predominates over his perceptive powers, he is so much more poet than artist, that he loses the beautiful in the suggestions, the reveries, the feelings it awakens, and this emotion is the value he found in beauty throughout his life." The Life of Edgar Allan Poe (Boston, 1909), I, p. 43.

${ }^{12}$ In another of the 1827 poems, "Visit of the Dead," Poe explored the concept of the human soul in its immediate and future state. Arthur H. Quinn writes that in this poem "there is a powerful conception of the relation of the soul, lonely so far as earthly ties are concerned but not lonely in the larger reality of death...." (p. 127). The first ten lines of the poem express Poe's belief in the individual soul's ultimate union wi.th all other souls in an after-life as yet undetailed in his poetic imagination:

Thy soul shall find itself alone-Alone of all on earth--unknown

The cause--but none are near to pry

Into thine hour of secrecy.

Be silent in that solitude,

Which is not Ioneliness--for then

The spirits of the dead, who stood

In life before thee, are again

In death around thee, and their will

Shall then o'ershadow thee - be still:

(Tamerlane and Other Poems, p. 27, 11. 1-10) 
Certainly one aspect of "Tamerlane" most important to this analysis is Poe's treatment of the conflict between the intellect and the spirit. Tamerlane realizes too late the price he had to pay for exercising his human pride and ambition. Despite his earthly achievements, acquired through heartless intellect, his loss of the often dreamed of paradise of beauty leaves him in despair. At the beginning of the 1827 version of the poem, in a kind of confession, he tells the friar:

I have sent for thee, holy friar;

But 'twas not with the drunken hope, Which is but agony of desire

To shun the fate, with which to cope

Is more than crime may dare to dream

That I have call'd thee at this hour:

Such father is not my theme--

Nor am I mad, to deem that power

of earth may shrive me of the sin

Unearthly pride hath revell's in--

I would not call thee fool, old man,

But hope is not a gift of thine;

If I can hope ( 0 God! I can)

It falls from an eternal shrine.

$(11: 1-14)^{13}$

In the 1829 version of "Tamerlane," almost identical with the final version of 1845, Poe repeats and expands the concept of "an eternal shrine," as opposed to an earthly power, as the only source of human hope:

You call it hope--that fire of fire?

It is but agony of desire: 
If I can hope--Oh God! I can--

Its fount is holier--more divine--

I would not call thee fool, old man,

But such is not a gift of thine.

$$
\text { (VII, p. 1, 1i. 7-12) }
$$

At the end of the poem, the emotion has turned from deep sorrow, to deeper despair, and finally to a recognition of hope through death, as Tamerlane recognizes the deception of life and the truth of death as the entrance to eternal happiness :

... Death who comes for me
From regions of the blest afar,
Where there is nothing to deceive,
Hath left his iron gate ajar,
And rays of truth you cannot see
Are flashing thro' Eternity--
(VII, p. 8, 1I. 223-228)

Truth or the ultimate reality is now recognized by Tamerlane as having been apart from his personal life experience, which has had as its primary motivation excessive pride and ambition. In his final hours, he becomes completely aware of the most significant human loss that the poet could conceive: his imagination. Eric Carlson writes of Tamerlane's new awareness: "In his death-bed confession, the once-proud Tamerlane has come to realize that time and the curse of his consuming ambition to conquer the Earth have deprived him of Love and his power of imaginative vision."14

${ }^{14}$ Carlson, p. 565 . 
Tamerlane's ability to experience the ultimate joy of spiritual vision has been negated by the pride which has obscured from his view the prerequisites for such a vision: love and beauty. It remains for death, the final and unavoidable entrance into the realm of the spirit, to eliminate them all as the ultimate truth of man's destiny.

In "Tamerlane" love is elevated as an "idol...in the holy grove," the beauty of which, by a seeming design of nature, is blurred from man's view by worldly considerations. There seems no hope for happiness and peace in life, and death alone holds the promise of lasting truth and beauty. What Tamerlane has lost is for man the passageway in life to at least a glimpse of "rays of truth...flashing thro" Eternity." It seems that Poe had recognized early in his career the folly of earthly pursuits, the deception of what is generally accepted as reality among ordinary men, and the necessity of constantly seeking the absolute reality which lay just beyond man's consciousness. For Poe the imagination, the world of dreams and reveries, was the faculty which allowed man temporary passageway to this absolute reality. ${ }^{15}$ And, especially for Poe, it was a method of escaping the

15. H. Davidson writes of Poe's approach to reality in relation to "Tamerlane": "The poem becomes a set of allegorical stances whereby the young Tamerlane bends all exterior reality to his own will.... The Tamerlane (or Poe) method is to grant that the will has the power at every instant to make external reality into anything it wishes." Poe, A Gritical Study (Cambridge, Mass., 1957), pp. 8-9. 
"agonizing consciousness of consciousness," which plagued him with experiences of physical and psychological suffering. 16 He wrote to John Neal in 1829: "I am young--not yet twenty--am a poet--if deep worship of all beauty can make me one--and wish to be so in the common meaning of the word. I would give the world to embody one half the ideas afloat in my imagination." 17

Like most conscious (and conscientious) artists, Edgar Allan Poe seemed never to be completely satisfied with his poetry and very often revised a poem several times to achieve the effect he desired. ${ }^{18}$ Aside from the fact that his revisions invariably greatly improved the poem, it is interesting to note the poet gradually removing himself as the recognizable subject and generalizing an idea or an experience in his attempt to conceal its relationship to his life. Davidson writes that "...the poetic process required that the ostensible subject be somehow dramatized in a masquerade which would conceal the true meaning beneath the ostensible one. Nearly all of Poe's later revisions are directed toward

${ }^{16}$ For Poe's most direct expression of the suffering of his early years, see his letters to John Allan in Ostrom, I, pp. 4-50.

$$
17 \text { Ostrom, I, p. } 32 \text {. }
$$

${ }^{18}$ An excellent discussion of Poe's many revisions can be found in Margaret Alterton and Hardin Craig, "Introduction," Grar Allan Poe (New York, 1962), pp. Ixxvii-cxviii. (First blished in 1935.) 
this act of concealment or in making generalized some specific, even commonplace, theme."19

One such poem which seems to suggest by its several revisions a kind of evolution of thought, having its origin in Poe's early years, is "A Dream Within a Dream." The poem appears in three stages: In the 1827 collection it was titled "Imitation;" in the 1829 volume it appeared as "To -- --;" and in Flag of Our Union, March 31, 1849 it became "A Dream Within a Dream."20 The three versions, despite the revisions, are linked by the theme of the dream. Illusion as the only reality in which happiness can exist in this poem seems to replace the lost hope of "Tamerlane," and marks, early in Poe's career, the beginning of his world of vision. Hardin Graig writes of the evolution of this poem:

The interesting feature of the history of the poem is the fact that Poe continued to meditate on the theme of the transitoriness of his life. In the earliest version life has been like a dream, and he is willing to let it pass. Into the 1829 form comes the figure of the sands sifting through his fingers; life seems paltry, but he will endure it. Into the latest versions comes the conclusion that life is like a dream within a dream. The poem grows less and less autobiographical.

What is most significant about this poem is that the important place of dreams and illusions in the poet's youth

${ }^{19}$ Poe, A Critical Study, p. 41.

${ }^{20}$ According to Hardin Craig, "At the time of his death, Poe was preparing to publish the poem again with still further slight revision in the Examiner of Richmond." "Notes," Edgar Allan Poe, p. 478 . 
seems clearly established, despite his attempts to conceal the autobiographical implications. In the 1827 version Poe repeats the theme of pride, already well-established in "Tamerlane," and introduces the concept of life as illusion:

A dark unfathom'd tide of interminable pride-A mystery, and a dream, should my early life seem; I say that dream was fraught With a wild, and waking thought of beings that have been, Which my spirit hath not seen, Had I let them pass me by, With a dreaming eye : (VII, p. $150,11.1-10$ )

It seems that as early as 1827 Poe was aware of the immeasurable depths of his characteristic pride and dreamlike quality of life as experienced by a mind possessing overwhelming powers of imagination. Even the title of the poem indicates that he had apparently already recognized a duality in life, an idea which he explored continuingly to greater degrees throughout much of his later writing. On the one hand there was the reality of the "waking thought" and on the other the seemingly deeper reality of the "dreaming eye." As in "Tamerlane," there appears in "Imitation" the suggestion that the will is capable of controlling, through man's imagination, the appearance of reality: "Those thoughts $I$ would control, / As a spell upon his soul" (VII, p. 151, 11. 13-14). The second or 1829 version of "A Dream Within a Dream" was titled "To -- - " and was doubled in length wi th four numbered sections. The original themes of pride and the 
dream were retained, but to these Poe added two more ideas indicative of his developing concepts. The first of these ideas is expressed in the third section of the poem:

And I hold within my hand
Some particles of sand--
How few! and how they creep
Thro'my fingers to the deep:
My early hopes? no--they
Went gloriously away,
Like lightning from the sky
At once--and so will I.
(VII, p. 152, 11. 19-26)

Here Poe treats both the past death of hope and the ultimate death of human existence as violent and catastrophic, likening it to "lightning from the sky." In later tales and essays, he often repeated the concept of catastrophic destruction, and in Gureka it became an important aspect of his final poetic vision of the inevitable collapse of the universe. One might speculate, however loosely, that his choice of the word "gloriously" in the previously quoted lines indicates the degree to which he had, by this time, considered the relationship of immediate, violent destruction and the end of the universe.

In the fourth section of the 1829 version, Poe expressed a reaction to the condition of human existence which marked an early manifestation of an attitude characteristic of much of his later work: "In the terror of my lot / I laugh to think how poor / That pleasure 'to endure:' (VII, p. 152, 11. 19-26). The terror of life and the dissatisfaction of simply enduring it seem to blend with the inherent pride of 
the poet to result in the final reaction in the last line: "Endure!--no--no--defy" (VII, p. 152, 11. 19-26).

The last published version of "A Dream Within a Dream" appeared in 1849 and combined in twenty-four lines the various aspects of the two earlier poems: The lost hope, the torment of a life quickly passing, and the uncertainty of the reality of existence. By this time Poe was able to write without hesitation: "All that we see or seem / Is but a dream within a dream" (VII, p. 16, 11. 10-11). Davidson writes of this poem:

The poem has certain autobiographical implications; more importantly, the subject relates to Poe's conjectures on the differences between the presumed reality which men think exists and the true reality of mind beyond the illusions of this world--a theme he would investigate more completely in "Al Aaraaf." 22

Although this discussion has included only two of the poet's 1827 poems, and one might take issue with this treatment as very selective, it seems evident, nevertheless, that by that date Poe had contemplated man's condition in both its physical and spiritual states and had arrived at conclusions which probably formed the basis of his later, more developed theories. ${ }^{23}$ He had questioned the meaning of reality, seen in his dreams the potential of imagination, and had

${ }^{22}$ Selected Writings of Edgar Allan Poe (Cambridge, Mass., 1956), p. 487 .

23 There are several other of the 1827 poems which also contain the characteristic themes of Poe's early years. In 
begun to explore the meaning and results of death. He had prepared the way for a deeper and more exact exploration, through his later works, of the cosmic laws which govern man's existence.

The prelude to a long poetic examination of the cosmos came in a poem of 1829, "Sonnet--To Science." Eric Carlson writes of this poem: "In its place and theme, this sonnet served to introduce 'Al Aaraaf,' which followed immediately in the edition of 1829." 24 Edward $H$. Davidson says further that the poem "attempts...to establish the difference between man's rational and imaginative powers."25 It seems rather certain that Poe's consideration of science in his searching for answers to the complexities of man's existence led him to a further consideration of the relative value of reason and intuition. Although he was reasonably well versed in science by this date and would continue his readings in that subject,

"Dreams" he repeated the theme of illusionary happiness: "I have been happy, tho" in a dream" (1. 27).* "The Lake" combines a haunted and lonely natural environment with the poetic vision of death as a final release:

Death was in that poison'd wave And in its gulf a fitting grave For him who thence could solace bring To his dark imagining;

Whose wild'ring thought could even make An Eden of that dim lake.

*Tamerlane and Other Poems, pp. 26-34. ${ }^{24}$ Carlson, p. 558 .

${ }^{25}$ Selected Writings, p. 487. 
he recognized its limitations. 26 out: "Science, he believes, does not reveal things as they really are. Science 'alters' all things, and the true reality lies in the poet's heart. He sees man and Nature as a whole, not in isolated sections." 27

Poe's concern for the alterations of science is evident in the first two lines of the sonnet: "Science! true daughter of old Time thou art! / Who alterest all things with thy peering eyes" (VII, p. 22, 11. 1-2). The next six lines seem to reaffirm his rebellion against "dull" reality and his continued exploration of the world of dreams as a source of a deeper reality:

Why preyest thou thus upon the poet's heart, Vulture, whose wings are dull realities? How should he love thee? or how deem thee wise, Who wouldst not leave him in his wandering To seek for treasure in the jewelled skies, Albeit he soared with an undaunted wing? (VII, P. 22, 11. 3-8)

Poe's reaction takes on a more personal quality in the last lines of the poem, as he appears to be describing the

${ }^{26}$ In Israfel Hervey Allen writes: "Although Poe has been accused of dabbling in science,' his interest and spectlations about it were at least a half century in advance of his time.... Poe was one of our first literary men really to have his imagination stirred by science" (pp. 412-413). Speaking of Poe at the 1829 publication of Al Aaraaf and Other Poems, A. H. Quinn writes: "Poe already was a reader of scientific works, and was to show all his life a keen interest in them" (p. 162). See f.n. 5, above.

${ }^{27}$ Quinn, p. 162 . 
influence of science on his private world of dreams: "Hast thou not torn the Naiad from her Flood, / The Elfin from the green grass, and from me \% The summer dream beneath the tararind tree?" (VII, p. 22, 11. 13-14).

Far from being simply an attack on science and its mundane and systematic discoveries, "Sonnet--to Science" is more probably the proclamation of another, even greater approach to an awareness of the complexities of existence. As Davidson writes:

The sonnet attacks the delusion of modern man that he can reduce the phenomenal universe to his own convenient, measurable detail; it is reaffirming... that nature has wonders and comprehensible systems far beyond the trivially limiting perspective of "science" or man.... In..." Sonnet--To Science,"...he was struggling for the organic principle which he may never have achieved until many years later in Eureka....28

One poem which brought him closer to realizing this achievement is "Al Aaraaf," which, in part, is an attempt allegorically to portray the fall of man. It appeared in 1829 in Al Aaraaf, Tamerlane and Minor Poems, published in Baltimore, and represents the poet's first serious literary treatment of his developing cosmic theories. In a letter to Isaac Lea, dated May, 1829, Poe attempted an explanation of the origin and meaning of the poem: 
Its title is "Al Aaraaf"--from the Al Aaraaf of the Arabians, a medium between Heaven \& Hell where men suffer no punishment, but yet do not attain that tranquil \& even happiness which they suppose to be the characteristic of heavenly enjoyment.... I have placed this "Al Aaraaf" in the celebrated star discovered by Tycho Brahe which appeared \& disappeared so suddenly-It is represented as a messenger star of the Deity, \&, at the time of its discovery by Tycho, as on an embassy to our world. One of the peculiarities of Al Aaraaf is that, even after death, those who make choice of the star as their residence do not enjoy immortality--but, after a second life of high excitement, sink into forgetfulness \& death--This idea is taken from Job. 29

A complicated blending of philosophy, religion, history and science, "Al Aaraaf" personifies and exalts beauty in the figure of Nesace, the Spirit of Beauty, whose mission it is to bring supernal Beauty to other worlds and to prevent the spreading of man's guilt in not searching for beauty:

What tho' in worlds which sightless cycles run, Link'd to a little system and one sun-Where all my love is folly, and the crowd Still think my terrors but the thunder cloud, The storm, the earthquake, and the ocean-wrath-(Ah! will they cross me in my angrier path?)

${ }^{29}$ Ostrom, I. pp. 18-19. For two interesting and opposite views of Poe's general purpose in "Al Aaraaf" and his specific treatment of Nesace ("Agent" or "Messenger"), see Floyd Stovall, "An Interpretation of Poe's 'Al Aaraaf"," University of Texas Studies in English, IX (1929), 106-133

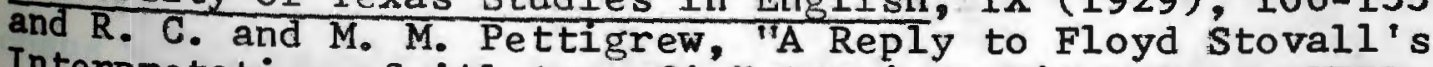
Interpretation of "Al Aaraaf'," American Literature, VIII (1937), 439-445. For further background, interpretation, and a discussion of the influence of Coleridge, Moore, Byron, and Milton, see W. B. Cairns, "Some Notes on Poe's "Al Aaraaf" "Modern Philology, (May, 1915), 35-44. The thematic relationship of "Al Aaraaf" and later works by Poe is discussed in Robert D. Jacobs, "Poe's Earthly Paradise," American Quarterly. XII (Fall, 1960), 404-413. 
What tho' in worlds which own a single sun The sands of Time grow dimmer as they run, Yet thine is my resplendency, so given To bear my secrets thro" the upper Heaven. Leave tenantless thy crystal home, and fly, With all thy train, athwart the moony sky-Apart--like fire flies in Sicilian night, And wing to other worlds another light! Divulge the secrets of thy embassy To the proud orbs that twinkle--and so be To ev'ry heart a barrier and a ban lest the stars totter in the guilt of man: (VII, pp. 28-29, 11. 133-150)

The cause of man's fall is symbolically portrayed in Part II through the story of Angelo and Ianthe, the two lovers whose "'passionate love' blinded them to absolute Beauty." "Al Aaraaf" continues to express Poe's belief in the limitations of reason in discovering man's place in the cosmic scheme. In his "Notes" to "Al Aaraaf," Eric Carlson writes: "It is only through insight and imagination that man can achieve salvation and recover his lost Eden, his power to see pure beauty and ideality; meanwhile he suffers disorder, and death to his soul."30 "Insight" and "imagination," as expressed here, would evolve ultimately to become the "intuition" of Eureka.

The cosmic allegory ends with the fading into nothingness of the two lovers, but not before Angelo describes the chaos which results from man's inability to search for supernal Beauty:

${ }^{30}$ Carlson, p. 558 . 
But, list, Ianthe! when the air so soft Fail'd, as my pennon'd spirit leapt aloft, Perhaps my brain grew dizzy--but the world I left so late was into chaos hurl'd-sprang from her station, on the winds apart, And roll'd, a flame, the fiery Heaven athwart. (VII, p. $38,11.231-236$ )

In a total view, there are several very interesting aspects of "Al Aaraaf" which indicate an important stage in the evolution of Poe's concepts. The first can be found in the song of Nesace, of which Stewart writes: "Though humans conceive of God after a model of their own, He has revealed himself as a star" (VII, 156). Also, A. H. Quinn views the following lines "as being suggestive of the concepts expressed in Eureka": 31 "Worlds which sightless cycles run, / Link'd to a little system and one sun--" (VII, p. 28, 11. 133-134). Finally, as indicated earlier, both the emphasis on intuition as a source of higher truth and the seemingly prophetic description of the catastrophic destruction of man and earth indicate that Poe's searching, as early as 1829 had brought him close to the concepts expressed much later in Eureka.

In examining the possible themes of "Al Aaraaf," E. H. Davidson concludes that one suggested theme is

that of the Apocalyptic vision of a final catastrophe, the total annihilation of man and the terrestrial universe in which Poe himself literally believed and 
which he treated in several of his tales. (This event has not yet taken place because Ianthe and Angelo can still see the world; it might have taken place had Poe written the subsequent two parts of the poem.) 32

In the crystallized theories of Eureka, Poe envisions a cosmic cycle of expansion and contraction of the "Primordial Particle" as it alternately creates the diffused universe and catastrophically returns it to its original state of Unity or Nothingness. Of this theory in relation to Poe's early poetry, Eric Carlson writes:

The dream motif of the 1827 poems reflects mainly Youth's aspirations toward perfection, the carpe diem theme, and the idea of loyalty in love. By 1829, the dream has become a vision of supernal Beauty calied "Al Aaraaf," the Edenic world of poetic harmony and imagination, from which "passionate" man has fallen. At the approach of Al Aaraaf, Earth had trembled and succumbed to chaos. Thus the consequent human condition is one of unrest, sorrow, and, most of all, either the doom of "silence" or the fateful choice between "Discovery" and Death. 33

In April, 1831, Elam Bliss published Poems by Edgar A. Poe, Second Edition in New York, a volume containing, accord-

\section{Selected Writings, p. 489. \\ 33}

Carlson, p. xxiv. In the "Introduction" to Edgar Allan Poe, Hardin Craig writes of the relationship of beauty and order in Poe's mind as evidenced in "Al Aaraaf": "It is interesting to attempt to reconstruct from the young poet's writings of these early years what seems unmistakably to have been a struggle surging through his mind between first intimations that reason might prove salutary in his literary art and his reluctance to permit reason to fasten itself upon his effervescing thought.... Poe had expressed in poetic form in 'Al Aaraaf,'... something of the significant struggle that was now going on in his mind, for in 'Al Aaraaf' Poe not only exalts imagination and dreams but also beauty as order." p. Ixxxvi. 
ing to A. H. Quinn, "poetry of a kind that had not yet been written in the English language. " 34 One poem in that collection through which Poe continued his examination of the human condition was "The Doomed City," later titled "The City of Sin" (1836) and finally titled "The City in the Sea" (1845). It is also worth noting that the 1845 printing of this poem carried the sub-title, "A Prophecy." 35 Speculations on the origin of this poem are many, ranging from Louise Pound's statement, "It owes little to the work of his predecessors or his contemporaries ${ }^{11^{36}}$ to H. M. Beldon's argument that Poe's source was Dante's Inferno; specifically, the City of Dis. ${ }^{37}$ However, the most often repeated source, and certainly most important to this discussion, is the Bible.

The Biblical references appear to have their source in the stories of ancient cities like Gomorrah, whose people were punished by God for their sins and had their society

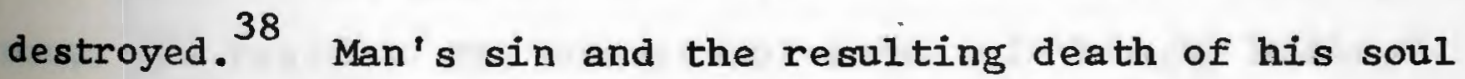

${ }^{34}$ Quinn, p. 185 .

${ }^{35}$ Louise Pound, "On Poe's 'The City in the Sea:" American Literature, VI (March, 1934). 22.

36 Ibid.

37 "Poe's City in the Sea and Dante's City of Dis," American Literature (November, 1935), 332-334.

${ }^{38}$ For discussions of the influence of the Bible on Poe's poetry see W. M. Forrest, Biblical Allusions in Poe (New York, 1928) and Kilis Campbell, "Poe's Knowledge of the Bible," Studies in Philology, XXVII (1930), 546-552. 
are the central ideas of this poem, as Poe described the silent city beneath the sea:

Io: Death has reared himself a throne

In a strange city lying alone

Far down within the dim west

Where the good and the bad and the worst and the best Have gone to their eternal rest.

There shrines and palaces and towers

(Time-eaten towers that tremble not!)

Resemble nothing that is ours.

Around, by lifting winds forgot,

Resignedly beneath the sky

The melancholy waters lie.

No rays from the holy heaven come down

On the long night-time of that town;

But light from out the lurid sea

Streams up the turrets silently--

(VII, p. 49, 11. 1-15)

There are echoes of "Al Aaraaf" in this description,

making possible the conclusion that the city is a microcosm of the earth, and possibly the universe. ${ }^{39}$ The city has been left intact, though on the brink of complete collapse, having been engulfed at the height of its material development. It rests in the silent splendour of "kingly halls," "Babylon-like walls," and "the gaily-jewelled dead," but there is no peace or beauty. The seas are "hideously serene" above "gaping graves," and "No rays from the holy heaven come down / On the long night-time of that town" (VII, p. 49, 11. 12-13). There is silence, but not peace; splendour, but not beauty; death, but not spiritual transi- 
tion. There is only the emptiness of the void in what we are to imagine was once a civilization. Of Poe's landscape description in general and "The City in the Sea" in particular, Federico Olivero offers some enlightening observations:

Landscape description was to Poe an artistic device to express his personal emotions...in "The City in the Sea," the enchanted ocean seems to hide Death's palace; its depths are haunted by dismal visions.... It is a gloomy world he lets us in; his fantastic universe is only gleaming here and there with faint splendour, or red fires; nevertheless, the murky atmosphere is sometimes pierced by violet beams, by rays of a mystic sun, is kindled by open flames, by a purple lustrousness.... Poe tries to bestow upop his emblematic

Of all Poe's treatments of the theme of death in the poetry through 1831, the one most repeated and also most closely related to his final concepts can be found in "The Sleeper." Appearing first under the title "Irene," this poem was thought by Poe to be one of his best. He wrote to George W. Eveleth in a letter dated December 15, 1846:

Your appreciation of "The Sleeper" delights me. In the higher qualities of poetry, it is better than "The Raven"--but there is not one man in a million who could be brought to agree with me in this opinion. The Raven, of course, is far the better as a work of art--but in the true basis of all art The sleeper is the superior. I wrote the latter when quite a boy. 41

\footnotetext{
40 "Symbolism in Poe's Poetry," Westminister Review,
(1913), 201, 203, 207.

${ }^{4 I}$ ostrom, II, p. 332 .
} 
Davidson writes that the poem "seems to contain just about all the Poesque and nineteenth-century trappings pertaining to dead beautiful girls, "42 and, as far as it goes, this conclusion appears reasonable. What is more important, however, is the specific treatment of death in terms which seem to relate clearly to a total view of existence. Death is not a void, but, as implied in the title and throughout the poem, it is a sleep. In fact, it is a "conscious slumber" which permeates not only human life but also plants ("rosemary," "lily"), the "ruin," which "moulders into rest," "the lake," and, finally, "All Beauty." The slumber is peaceful, but, as Carlson interprets it: "Almost throughout, the dominant tone is one of apprehension that the peace of soul which has come to Irene through death will be destroyed by the phantom fears of the living. The constancy of her grieving lover (the speaker) transfigures Irene into a symbol of ideal peacefulness of spirit." 43

Peaceful or not, death, rather than an end, is a beginning. Davidson, in another analysis of "The sleeper," takes a closer look at the theme of death and offers a brief statement of the direction Poe's explorations have taken from his first published poetry to 1831 :

\footnotetext{
${ }^{42}$ Selected Works, p. 494. ${ }^{43}$ Carlson, p. 567.
} 
This poem is one of Poe's early statements on the belief that, while there is death, no one really dies. Death is a "sleep," or a transition from one stage of existence to another.... From "Tamerlane" through "The Sleeper" we explore aspects of the inner self or pro-
found mysteries concerning the exterior world. 44

Although the poetry from 1827 to 1831 indicates that his intellectual probing had led him tossome reasonably definite conclusions, for Poe the exploration had really just begun. The poetry and prose tales which were to come would rework and make more explicit the concepts ultimately defined in Eureka. 


\section{EARLY TALES: THE MAELSTROM EXPLORED}

If the early poetry through 1831 indicates an embryonic stage in Poe's evolving cosmic concepts, the tales from 1832 through 1838 suggest that those concepts were beginning to mature and develop as he himself had begun to develop another medium of expression in the prose tale. The transition from poetry to prose fiction as a dominant form of expression appears to be an important factor in the development of Poe's theories. Davidson writes:

When poetry failed or was abandoned in Poe's midcareer, the prose tale became a substitute means of working toward that intuitively apprehended realm where fact and idea, substance and concept might meet. In a "prose-poem" Eureka the two elements were joined; along the way, however, a number of artistic and symbolic pathways had to be explored, sometimes in much the same way as the poetry had sought them out, before full exploitation of the narrative form could be realized. 1

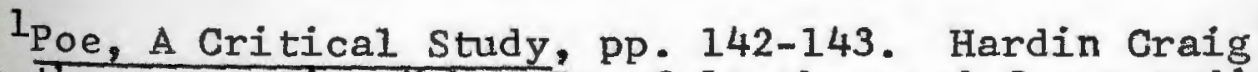
offers the suggestion "that Poe felt the need for a medium that would lend itself more readily than poetry to the exploitation of structure and that he recognized in prose a better vehicle than in poetry for concentrated thinking and writing" (Poe, p. xc). Other critics view Poe's change in form as an indication that he recognized the short story as a means to remove himself from the grips of poverty; see Allen, Israfel, pp. 278-301, and Woodberry, life of Poe, pp. 97-110. See also C. S. Baldwin, "Poe"s Invention of the Short Story," American Short Stories (New York, 1904), pp. 15-22, and Napier Wilt, "Poe's Attitude toward his Tales," Modern Philology, XxV, 101-105. 
The eariiest of Poe's tales appeared in The Philadelphia Saturday Courier, five of which were published between January 14 and December $1,1832 .^{2}$ of these tales, witten in 1831 and submitted to the editors of the Courier in a contest offering a prize of one hundred dollars, an editorial appearing in the Baltimore Saturday Visitor on August 4, 1832, expresses a very favorable contemporary critical comment:

Mr. Edgar A. Poe, has favoured us with the perusal of some manuscript tales written by him. If we were merely to say that we had read them, it would be a compliment, for manuscripts of this kind are very seldom read by any one but the author. But we may further say that we have read these tales every syllable, with the greatest pleasure, and for originality, richness of imagery and purity of the style, few American authors in our opinion have produced anything superior. With Mr. Poe's permission we may hereafter lay one or two of the tales before our readers. ${ }^{3}$

The first of these published, "Metzengerstein," is a tale of Gothic horror in which Poe repeats the themes of sin and death, treated so often in his early poetry, and presents the concept of metempsychosis, which he developed more extensively in later tales. ${ }^{4}$ Although there are several

2

The five stories published in the Courier were: "Metzengerstein," "The Duc de L'Omelette, "A Tale of Jerusalem, "Loss of Breath" and "Bon Bon." For discussions of the dispute concerning the group to which the above five tales belong, see "The Tales of the Folio Club" in A. Quinn, pp. 745-746 and T. O. Mabbot, "On Poe's Tales of the Folio Club" Sewanee Review, XXXVI, 171-176.

3 A. H. Quinn, pp. 194-195.

"Metempsychosis, or the transmigration of souls, is also treated in "Moreila" (1835), "Ligeia" (1838), and "A Tale of the Ragged Mountains" (1844). 
points of view relative to the origin of this tale, it is generally accepted to be a parody of the German tales of horror, a conclusion reinforced by the sub-title of the 1836 publication, "A Tale in Imitation of the German." 5

The story opens with Poe's characteristic effort to lend credulity to his less than scientific subject by citing several sources to support its existence, or at least the possibility of existence, while the narrator maintains for himself a neutral position, neither believing nor disbelieving. From this apparently objective point of view, he begins his tale of the feuding families of Berlifitzing and Metzengerstein, whose mutual hatred, though centuries old, has reached its highest degree of hostility. Wilhelm, Count Berlifitzing, is a "doting old man," and Frederick, Baron Metzengerstein, is a young man of eighteen whose rise to the head of his family is accompanied by wild and treacherous behavior.

Apparently guided by an ancient prophecy, the spirit of a horse pictured on a tapestry is transferred to the body of another in order to exact the punishment of the Baron Frederick, whose sins and those of his family find what appears to be their just reward in a vengeful and catastro-

5For further discussion of the influence on Poe of the then currently popular tales of terror, see Edith Birkhead, The Tale of Terror (London, 1921), pp.185-220; Oral S. Coad, "The Gothic Element in American Literature before 1835," Journal of English and Germanic Philology, XXIV, 72-93; E. H. Davidson, Poe, A Critical Study, PP. 105-i35; P. E. More, "Origins of Hawthorne and Poe," in Shelburne Essays, First

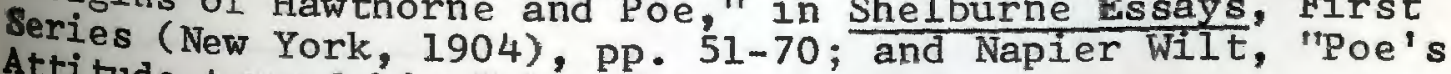
Attitude toward his Tales." 
phic holocaust. As in many of Poe's tales, the relationship of character and setting is most important. Frances Winwar writes that "the atmosphere of grandeur surrounding the inner evil of a soul is so suggestively evoked that it is as much an active part of the tale as the character of Metzengerstein, or the steed that rode him into the flames of hell which he himself had created."6

Another aspect of this tale, as important an indication of Poe's developing theories as the apocalyptic ending, is the condition of the protagonist immediately before his destruction. Frederick's inability to distinguish illusion from reality in his state of intense anxiety and heightened perception results in a series of compulsive reactions to an environment at once familiar and capricious. While meditating in the "vast and desolute upper apartment of the family palace," amid swaying, gloomy tapestries, as the stables of the Castle Berlifitzing were burning, his vision becomes uncontrollably fixed on "the figure of an enourmous, and unnaturally coloured horse." His staring and agitated condition are inexplicable and unnatural as he reacts to the mysterious force:

On Frederick's lip arose a fiendish expression, as he became aware of the direction which his glance had, without his consciousness, assumed. Yet he did not remove it. On the contrary, he could by no means account for the overwhelming anxiety which appeared 
falling like a pall upon his senses. It was with difficulty that he reconciled his dreamy and incoherent feelings with the certainty of being awake. The longer he gazed, the more absorbing became the spell-- the more impossible did it appear that he could ever withdraw his glance from the fascination of that tapestry. (II, p. 189)

The Baron's subsequent horror at the realization of the changed position and appearance of the horse, his later discovery of and "perverse attachment" to the horse's counterpart, and the terror-filled, compulsive series of riding experiences are all part of the prelude to sudden and violent destruction, greatly paralleling Poe's treatment of similar catastrophes in later tales and Eureka. There is intertwined both a terror of and resignation to the imminent cataclysm. The characteristic "shriek" in "Metzengerstein" comes from the one destroyed, but in later tales its origin is transferred by Poe to the force responsible for the catatrophic destruction. 7 In the final scene of destruction there is the suggestion of a prophetic revelation which appears to be repeated and developed throughout many of Poe's later tales:

Up the long avenue of aged oaks... a steed, bearing an unbonneted and disordered rider, was seen leaping with an impetuosity which outstripped the very Demon of the Tempest. The career of the hor seman was indisputably, on his own part, uncontrollable.... One

7 The shriek or yell in later works comes from the wirlpool or Maelstrom, the force of destruction in "MS. (18und in a Bottle" (1833), "A Descent into the Maelstrom" (1841), and The Narrative of Arthur Gordon Pym (1838). 
instant, and the clattering of hoofs resounded sharply and shrilly above the roaring of the flames and the shrieking of the winds--another, and, clearing at a single plunge the gate-way and the moat, the steed bounded far up the tottering staircases of the palace, and, with its ${ }_{8}$ rider, disappeared amid the whirlwind of chaotic fire.

On October 19, 1833, "MS. Found in a Bottle" appeared

in the Baltimore Saturday Visitor, and in it Poe exchanged

fire for whirlpool as the symbolic force of destruction. 9

In his reaction to Nathaniel Tucker's criticism of this

story, Poe wrote in 1835:

Your opinion of "MS. Found in a Bottle" is just. The Tale was written some years ago, and was one among the first I ever wrote.... What articles I have published since Morella were all written some time ago. I mention this to account for the "mere physique" of (page 2) the horrible which prevails in the "MS. Found in a Bottle." I do not think I would be guilty of a similar absurdity now. 10

Whether or not the tale is absurd, as Poe would seem to have it, is certainly open to question, particularly since it marks the beginning of his use of a major characteristic

${ }^{8}$ II, p. 196. It is interesting to note the description of the flames as a "whirlwind of chaotic fire," a possible foreshadowing of Poe's later use of the whirlpool.

${ }^{9}$ See f.n. 79, above. Opinions on the origin of this tale range from Floyd Stovall's comparison with "The Ancient Mriner" in "Poe's Debt to Coleridge" to J.A. Bailey's suggestion that Poe was most indebted to an 1820 novel by capt. Adam Seaborn, titled Symzonia. "Sources of Poe's Arthur Pym, 'Hans Pfaal,' and other pieces" PMLA, LVII (hane, 1942), 513-535.

${ }^{10}$ ostrom, pp. 77-78. 
oymol. Eric Carlson writes: "The whirlpool is Poe's most obsessive image of the human condition: in a heedless universe man is swept down in fear and dread to almost certain death.

Il In several of $\mathrm{Poe}^{\prime}$ s later tales the whirlpool is the symbolic force of destruction, towards which individuals, families and, ultimately, the earth are drawn uncontrollably. Richard Wilbur, while recognizing the symbolic value of the piral, offers a more psychological interpretation of its นse:

That Poe offers us so many spirals or vortices in his fiction, and that they should always appear at the same terminal point in their respective narratives, is a strong indication that the spiral had some symbolic value for Poe. And it did: What the spiral invariably represents in any tale of $\mathrm{Poe}^{\prime} \mathrm{s}$ is the loss of consciousness, and the descent of the mind into sleep.... The spiral or vortex is a part of that symbolic language in which Poe said his say, and unless we understand it we cannot understand Poe.12

Moreover, "MS. Found in a Bottle" introduces an important new theme more developed in Poe's later fiction, especially in his dnly long story, The Narrative of Arthur Gordon Pym. Of this theme Carlson writes: "MS. Found in a Bottle' develops the 'journey' and 'discovery' motifs used in other of his tales. The Major symbols...culminate in a

\section{I1 Introduction to Poe, p. xxv.}

12"The House of Poe," Poe, A Collection of Critical Sesays, ed. Robert Regan (New Jersey, 1967), p. 100. 
characteristic boundary situation--the Abyss of the Whirlpool--from which there is no exit."13

Poe's journeys may lead to discovery, but they lead also to destruction. The joy of revelation in the Christian sense is not to be found in the symbolic journeys of the tales, and it will only be approximated in the final visions of Eureka. Harry Levin characterizes Poe's discoveries:".. Poe had not the gift of serendipity, and his discoveries are never happy accidents; they are tantalizing glimpses into the structure of his luckless universe.... With Poe, the imaginary voyage becomes a catastrophic quest, a pursuit of exciting knowledge attained at the price of destruction."14

The protagonist-narrator is not an unusual one for Poe. ${ }^{15}$ He is a wealthy, highly educated, self-proclaimed skeptic, who is completely alone, having been alienated from both country and family. To establish the necessary air of credibility, Poe uses the same technique he employed many

\section{Introduction to Poe, pp. 574-575.}

14

The Power of Blackness, (New York, 1958), pp. 106107. of the vision to be experienced in the Abyss of the whirlpool, Carlson adds: "Through death as an imminent boundary situation, the narrator experiences a revelation, a philosophical "Iynxeye" discovery, or Man's place in the Universe." pp. xxxii.

15

For an excellent discussion of Poe's narrative tors," Bellege English, XXV (December, 1963), 177-181. Reprinted in Poe, A Collection of Critical Essays, ed. Robert Regan. (New Jersey, 1967), pp. 164-171. 
years later in Pym; that of relating the events of his tale through the main character's personal journal. The protagonist's self-description establishes his credibility:

I have often been reproached with the aridity of my genius; a deficiency of imagination has been imputed to me as a crime; and the Pyrrhonism of my opinions has at all times rendered me notorious. Indeed, a strong relish for physical philosophy has, I fear, tinctured my mind with a very common error of this age--I mean the habit of referring occurrences, even the least susceptible of such reference, to the principles of that science. Upon the whole, no person could be less liable than myself to be led away from the severe precincts of truth by the ignes fatui of superstition. (II, pp. 1-2)

Hardin Craig writes of this and similar passages:

As the danger grows, the narrator, now firmly established in his character of truth-teller, records all happenings with the same evident wish not to exceed the bounds of exact portrayal. It is, therefore, with little or no struggle that the reader yields credence to the story of the hulk tearing along with the tempest....16

As with many of Poe's later characters, Roderick Usher being a most notable example, the narrator of this tale is "haunted" by "a kind of nervous restlessness," which he gives as the reason for the sea voyage he takes aboard a ship bound for the Sundra islands. However, his destination is not the one he offers us on the conscious level but, rather, one which seems to rest in his subconscious mind, resulting in his haunting restlessness. His condition is 
characteristic of the Poe hero in general, about whom Davidson writes:

...he is the lonely one; he is the image of longing to get away... he must make his great decision or undergo the major trial in the waste places or in the solitude of the anguished soul... he must, to express himself, go above, away from, or beyond our Commoner range of experience in order to bring his message, the fire
from heaven....

From the very beginning, the circumstances of the ship and its environment create an air of apprehension while foreshadowing the imminent danger. The color of "a very singular isolated cloud," the "dusky-red" moon, the increasing transparency of the sea, the rapidly rising temperature, and the pervading calm lead the narrator to conclude: "I (was)...not without a full presentiment of evil. Indeed, every appearance warranted me in apprehending a Simoom" (II, p. 3). The refusal of the captain and crew to recognize the approaching storm may be viewed as a general unwillingness to recognize truth, and, as such, closely parallels the circumstances surrounding the catastrophic destruction in "Al Aaraaf," "The City in the Sea," and several of Poe's later tales. 18

\section{7poe, A Critical Study, p. 214.}

${ }^{18}$ In one of Poe's later tales, "The Colloquy of Monos and Una" (1841), Monos attributes the destruction of the earth to the fact that "the mass of mankind saw not, or, living lustily although unhappily, affected not to see." Works, IV, P. 205. 
The account of the ensuing Simoom and its destruction of all but the narrator and "an old Swede," though brief, is not without suspense. Arthur Quinn writes:

...the description of the "Simoom" is a good example of controlled exaggeration, in which also Poe was a master. The ancient ship, of deep black, hovering upon the sumit of a wave of more than a hundred times her own altitude, pausing for a moment of intense terror, then trembling, tottering and coming down upon the wreck from which the narrator is momentarily expecting to be hurled, is a fine example of suspense. 19

With the destructive violence of the storm behind them, the narrator and his companion approach what seems certainly to be the most symbolic and, therefore, most significant of their experiences. Before the force of powerful winds, the badly battered ship is propelled at rapidly increasing speeds, and, thus, embarks on its journey, uncontrolled by those aboard towards an unknown destination.

We scudded with frightful velocity before the sea, and the water made clear breaches over us.....For five entire days and nights... the hulk flew at a rate defying computation, before rapidly succeeding flaws of wind, which, without equaliing the first violence of the Simoom, were still more terrific than any tempest I had before encountered. our course for the first four days was, with trifling variations, S. E. and by S.; and we must have run down the coast of New Holland. (II, pp. 4-5)

The direction is significant, since Poe also used it in Pyow and was, in both instances, capitalizing on the contem- 
porary curiosity of various theories and discoveries relative to the South Pole. Woodberry writes of this curiosity:

Tales of the sea, under the influence of Cooper and Marryatt, were then at the height of their popularity, and many grew up and withered in a day. In selecting his subject, however, Poe was not merely adopting the literary fastion, but with the sure journalistic instinct that characterized him, was trading on the momentary curiosity of the public, which was highly interested in Antarctic explorations in consequence of the expedition thep fitting out under the
auspices of the government. 28 .

As the ship speeds south, the wind becomes extremely cold, the sun appears to be eclipsed and then extinguished by the sea, and darkness surrounds the ship. The narrator writes: "Thence-forward we were enshrouded in pitchy darkness....Eternal night continued to envelop us....All around were horror, and thick gloom, and a black sweltering desert of ebony" (II, pp. 5-6). Poe"s use of the color black here ynbolizes an important transition. Since the darkness is without the natural light of the sun, which has been extinguished "by some unaccountable power," it is also without life. Equally important is the inability to see, a significant aspect of this tale from the beginning and repeated later aboard the phantom ship. There is implied the darkness of vision, of knowledge, and of death.

\section{0}

relationfe of Poe, I, pp. 190-191. For discussions of Poe's royages, with Jeremiah Reynolds, who projected South Sea Ifteras, see Aubrey Starke, "Poe's Friend Reynolds," American serature, XI (May, 1939), 152-166, and A. Quinn, p. 640 . 
As the phantom ship comes crashing down from the "terrific height" of a giant wave, the Swede is killed, the hulk is destroyed, and the narrator is hurled onto the rigging of the strange ship, whose "hull was of a deep dingy black." Thus begins the final stage of the journey, which for the narrator is becoming less terrifying and more intriguing, as he realizes that he is on the brink of a discovery:

A feeling, for which I have no name, has taken possession of my soul--a sensation which will admit of no analysis, to which the lessons of by-gone times are inadequate, and for which I fear futurity itself will offer me no key.....I shall never--I know that I shall never--be satisfied with regard to the nature of my conceptions. Yet it is not wonderful that these conceptions are indefinite, since they have their origin in sources so utterly novel. A new sense--a new entity is added to my soul. (II, P. 9)

The "new sense" is supported by a new sign, the result of an accident (chance or the intervention of a greater power?): "While musing upon the singularity of my fate, I unwittingly daubed with a tar-brush the edges of a neatlyfolded studding-sail which lay near me on a barrel. The ludding-sail is now bent upon the ship, and the thoughtless touches of the brush are spread out into the word DISCOVARY***" (II, P. 10).

Finally, feeling and sign give way to a conscious wareness of destiny, as the narrator concludes: "It is evident that we are hurrying onwards to some exciting knowledge-some never-to-be-imparted secret, whose attainment is destruction" (II, p. 14). 
Something of Poe's symbolic use of color is necessary at this point, since it is evident that a change in color acompanies each major change of the narrator's circumstances. After the Simoom, the light of the sun disappears, leaving the narrator and his companion in "pitchy darkness." sverything is black including the phantom ship, which appears "a deep dingy black" on the pinnacle of a wave. Once aboard the strange ship, we encounter the predominant color of gray. The silent crew's "gray hairs streamed terribly in the tempest." The captain's "gray hairs are records of the past, and his grayer eyes are Sybils of the future." Finally, gray gives way to the white of the ice, as the phantom ship "thunders on to the southward with a velocity like the headlong dashing of a cataract." We journey from the black of blindness, to the gray of apprehension, to the white of discovery and death, as the ice parts and the ship plunges into the roaring whirlpool. 21

The attitude with which both the narrator and the crew accept their fate is worth noting. His fear becomes apprehension, which turns first to curiosity and, finally, to

\section{Richard Wilbur interprets the journey as a "sequence} of mental states": "MS. Found in a Bottle,' to give but one example, is an allegory of the mind's voyage from the waking world into the world of dreams, with each main step of the aarrative symbolizing the passage of the mind from one state to another-from wakefulness to reverie, from reverie to the hypnagogic state, from the hypnagogic state to the deep dream.... when the phantom ship makes its final plunge into has whirlpool, we are to understand that the narrator's mind "the gone over the brink of sleep and descended into dreams." "The House of Poe," p. 103. 
reconciliation. He says: "To conceive the horror of my gensations is, I presume, utterly impossible; yet a curiosity to penetrate the mysteries of these awful regions, predominates even over my despair, and will reconcile me to the most hideous aspect of death" (II, p. 14). The crew's last moments are described: "The crew pace the deck with unquiet and tremulous step; but there is upon their countenances an expression more of the eagerness of hope than of the apathy of despair" (II, p. 14).

"MS. Found in a Bottle" represents a significant stage in the development of Poe's Cosmic Myth. The presentation of the condition of man rushing uncontrollably towards his destiny of destruction in a heedless universe parallels his total view of the cosmos expressed in Eureka. The quasiscientific treatment of the setting and events of this 1833 tale became a characteristic of a great number of his later tales in which he continued to explore the condition and desting of man and through which he developed his total view of the cosmic cycle of "alternate dissolution and rejuvenescence." 22 "MS. Found in a Bottle" appears to be the first important narrative treatment of Poe's cosmic vision, the subject of which he later treated in various ways and to greater degrees in other tales, particularly in Pym.

${ }^{22} \mathrm{C}$. C. Walcutt concludes that Poe's use of "a tone of of entific veracity is a literary device.... it is--an element of style." "The Logic of Poe," College English, II (February, 194i), 438-444. 
One of those later tales in which Poe treats essenHally the same subject as that in "MS. Found in a Bottle" appeared in Graham's Magazine in 1841.23 "A Descent into the Maelstrom" differs from the earlier story, however, in that the narrator escapes the destruction of the whirlpool to retell his experiences in much the same way that coleridge's Ancient Mariner had. 24 In a letter dated July 12, 1841, to J. E. Snodgrass, Poe expressed an early opinion of the story: "You flatter me about the Maelstrom. It was finished in a hurry, and therefore its conclusion is imperfect. Upon the whole it is neither so good, nor has it been

${ }^{23}$ There are, of course, several other tales published between 1833 and 1841 which contain elements of Poe's developing concepts. "Berenice" (1835), "Morella" (1835), and "Ligeia" (1838) should be mentioned for their allegorical content and Poe's continued treatment of metempsychosis. See James W. Gargano, "Poe's 'Ligeia': Dream and Destruction," College English, XXIII (February, 1962), 337-342; James schroeter, "A Mísreading of Poe's "Ligeia'," PMLA, LXXVI (September, 1961), 397-406; and D. H. Lawrence, "Edgar Allan Poe," Studies in Classic American Literature, (New York, 1953), pp. 73-92. First published in 1922. Two other tales, "Shadow-A Parable" (1835) and "Silence--A Fable" (1837), should also be mentioned for their symbolism, use of astrological signs, and biblical qualities. Davidson writes of the latter tale: "What Poe is fumbling to express is the Idea he worked out with such care in Eureka: the history of the universe is an expression of a law; and that law states that all matter had a single locus, a primal Oneness, from which it was dispersed throughoutall space. In time the dispersive force will be withdrawn, and all matter will return to its primal unity, its Ur-condition again. What Poe was trying to express by the mystic word 'Desolation' was the presently observed state of total disunity and by the term "Silence' the inevitable coalescence of all substance." Poe, Coitical study, pp. 131-132.

${ }^{24}$ Por a discussion of the influence of Coleridge on Poe, see Floyd Stovall's "Poe's Debt to Coleridge." 
so popular as "The Murders in the Rue Morgue: 25 However, on June 2, 1844, he wrote to James $R$. Lowell that he considered "A Descent into the Maelstrom" one of his eight best tales. 26

The story begins with a rather extensive attempt to lend credibility to the experiences of the narrator, who, vith a companion to whom he relates his tale, is on a cliff overlooking the desolate ocean scene of his ordeal with the hirlpool. After having prepared his companion with an Introduction to his physical environment, and after both view the turbulent Maelstrom, the old man begins his tale. The appearance of the whirlpool in "A Descent into the Kaelstrom" and the sequence of events which follows closely parallel the same occurrences in "MS. Found in a Bottle." The old man describes the experience:

...never dreaming of danger....All at once we were taken aback by a breeze... This was most unusual-something that had never happened to us before--and

250strom, I. p. 175. Despite the fact that "A Descent into the Maelstrom" was not published until 1841, it is included here as one of Poe's early tales primarily because of its close thematio relationship to "MS. Found in a Bottle." Also, due to Latrobe's discussion of it as one of the stories submitted in the Baltimore Saturday Visitor contest of 1833, there is at least some reason to believe that it was written at that time. See Allen, Israfel, pp. 280281, and A. B. Benson, "Sources of Poe's 'A Descent into the Helstrom" "Journal of English and Germanic Philology, XLVI (Jily, 1947), $\frac{\text { Journal }}{298-301 .}$ 26.

Lsted Ibid., p. 258. The other seven tales which Poe Rue Morgue " "Ligeia," "The Gold-Bug," "The Murders in the Tale Heart," "The Fali of the House of Usher," "The Tell- 
I began to feel a little uneasy, without exactly knowing why.... looking astern, we saw the whole horizon covered with a singular copper-coloured cloud that rose with the most amazing velocity..... In less than a minute the storm was upon us....it became suddenly so dark that we could not see each other in the smack. (II, P. 235)

The breeze, the cloud, the storm, and the enveloping blackness constitute the prelude to the narrator's journey to discovery. His reactions follow the same pattern as those of the narrator in "MS. Found in a Bottle." At first he is terrified:

My elder brother...put his mouth close to my ear, and screamed out the word "Moskoe-strom!"....I shook from head to foot as if I had had the most violent fit of the ague. I knew what he meant by that one word well enough--I knew what he wished to make me understand. With the wind that now drove us on, we were bound for the whirl of the Strom, and nothing could save us! (II, p. 237)

Later, he resigns himself to his fate in despair: "It may appear strange, but now, when we were in the very jaws of the gulf, I felt more composed than when we were only approaching it. Having made up my mind to hope no more, I got rid of a great deal of that terror which unmanned me at first. I supposed it was despair that strung my nerves" (II, P. 239).

Finally, terror and despair give way to curiosity and the desire to continue his journey toward the depths of the Maelstrom: "After a little while I became possessed with the keenest curiosity about the whirl itself. I positively felt aish to explore its depths, even at the sacrifice I was 
going to make; and my principal grief was that I should never be able to tell my old companions on shore about the mysteries I should see" (II, P. 240).

The symbolic shift in color, from the blackness of intellectual darkness to the whiteness of discovered knowledge, although less emphasized here than in "MS. Found in a Bottle" and Pym, is, nevertheless, a significant aspect of the journey and discovery motifs. First, the darkness surrounding the scene is illuminated by the white light of the

moon:

Around in every direction it was still as black as pitch, but nearly overhead there burst out, all at once, a circular rift of clear sky--as clear as I ever saw--and a deep bright blue--and through it there blazed forth the full moon with a lustre that I never before knew her to wear. She lit up every thing about us with the greatest distinctness-(II, pp. 237-238)

Later after making his escape from the depths of the Melstrom lashed to a barrel, his once "raven black" hair turns white, a result of his terrifying ordeal and possibly a symbol of his intellectual illumination. What his revelation was is uncertain, although what he views and hears at the bottom of the abyss is described near the end of his tale:

The rays of the moon seemed to search the very bottom of the profound gulf; but still I could make out nothing distinctly, on account of a thick mist in which every thing there was enveloped, and over which there hung a magnificent rainbow, like that narrow and tottering bridge which Musselmen say is the only pathway between Time and Eternity. This mist, or spray, was no doubt occasioned by the clashing of the great 
walls of the funnel, as they all met together at the bottom--but the yell that went up to the Heavens from out of that mist I dare not attempt to describe. (II, Pp. 242-243)

Poe does not attempt to describe with any clarity what discovery we are to expect at the end of the journey until woch later in his career. However, by 1838 certain aspects of his final conclusions seem to have crystallized, at least to some extent. These aspects can be best understood by a recognition of the recurring themes in both his poetry and tales from 1827 to 1838. From the first questions of the meaning of reality, through his exploration of the world of dreams and imagination, to the conclusion that life is a dream within a dream; a nightmare to be endured until we rush uncontrollably into the vortex of annihilation, Poe was vearching for an awareness of the complex existence of man and his relationship to the universe. If he did not provide his characters with a clear vision at the end of their journeys, it is probably because he had none to give them, for he, himself, had a journey to complete.

Allan Tate writes of Poe's personal journey:

He is progressively mastered by one great idea, deeper than any level of conscious belief and developing to the end of his life at an ever increasing rate, until at last he is engulfed by it. It is his own descent into the maelstrom.

He arrives at it, or reaches the bottom of it, in Eureka, which he wrote in 1848, the year before his death.27 27 "The Angelic Imagination: Poe as God," The Forlorn
Demon (Chicago, 1953), p. 75. Tate continues with a bio- 
The next leg of Poe's intellectual journey would take the form of another sea voyage, and, although it would not result in complete revelation, it would be a longer and infinitely more complex journey than any he had taken before.

graphical possibility: "I shall not go so far as to connect, symbolically or prophetically, his death and the vision of the pit at the end of Eureka. We may only observe that the complete vision, of which the early works represent an approximation, immediately precedes his death." 


\section{ARTHUR GORDON PYM AND THE JOURNEY TO}

\section{COSMIC CONSCIOUSNESS}

One of the longest pieces of fiction Poe ever wrote came partly as the result of a suggestion made by James Kirk Pawlding, in March, 1836, that he "undertake a Tale in a couple of volumes. ${ }^{1}$ That tale took the form of The Narrative of Arthur Gordon Pym, the first three chapters of which appeared in two installments in the Southern Literary MesBenger near the end of 1836. In June, 1837, it was copyrighted by Harper's, and the full text was published in July, $1838 .^{2}$

ISidney Kaplan, "Introduction," The Narrative of Arthur Gordon Pym (New York, 1960), p. vii. Arthur Quinn cites Harper's as the source of a similar suggestion (p. 263). AII quotations from this work, hereafter cited as Pym, will be taken from Harrison's Works, volume III, with page numbers indicated parenthe tically.

${ }^{2}$ A. Quinn, p. 263. Many sources have been suggested as the origin of Pym: D. M. McKeithan proposes Duncan's The Mariners Chronicle and Morrell's A Narrative of Four Voyages in "Two Sources of Poe's "Narrative of Arthur Gordon Pym ", "Texas Studies in English, XIII (July 8, 1933), 116-137. Robert L. Rhea cites Captain Cook's A Voyage to the Pacific Ocean in "Some Observations of Poe $\frac{1}{5}$ Origins," Texas Studies in English, X (July 8, 1930), 135-146. J. O. hiley suggests that Poe is most indebted to Gaptain Adam seaborn's novel, Symzonia (1820). "Sources of Poe's Arthur Gordon Pym, "Hans Pfaal, and Other Pieces," PMLA, LVII (June, 1942), 513-535. See also Robert F. Almy, who demonstrates a connection between Pym and Symmes" theory of the hollow earth. "J. N. Reynolds: A Brief Biography with par Hoular Reference to Poe and Symmes," The Colophon, 
originally intended as a hoax, Pym, according to carlson, "developed into a true imaginary voyage...." ${ }^{3}$ In England, as well as in America, some critics were taken in by the book and treated it as an account of Pym's real experiences. 4 In any event, the work was not successful, either as a real or imagined voyage, and Poe himself described it as "a silly book. "5

The appearance of Pym mid-way through Poe's career marks a significant stage in the evolution of his Cosmic Whth, because the various themes he had treated in his poetry and early tales, recognized in this paper as fragments of his total concept, converge in this work of 1838 to form a narrative expression of the central conclusions in Eureka. E. H. Davidson writes:

In Pym are brought together and given full statement some of the basic concepts which have been

New Series, II, No. 2, (Winter, 1937), 227-245; Keith Huntress, "Another Source for Poe 's Pym," American literature, XV (March, 1944), 19-25; and Mozelle Allen, "Poe's Debt to Voltaire," Texas Studies in English, XV, 26-69.

3 Introduction to Poe, p. 575. 4

(Septemb review in Burton's Gentleman's Magazine, III the though unfavorable, indicates that the writer took the book as a true journal. A. Quinn, p. 264. See also Kaplan's "Introduction," p. vii.

${ }^{5}$ Ostrom, I, P. 130. Al though Pym was compared unfavarably to Swift's Gulliver's Travels in Burton's review (wee f.n. 4, above). Allen Tate has recently written: "... there are passages in... Pym that have the lucidity and intensity of swift." "The Angelic Imagination," The Forlorn Demon (Chicago, 1953), p. 62 . 
hitherto unresolved in Poe's poetry and tales. I therefore place the work at what I call "center"; it stands, as it were, between the poetry and the fully mastered prose in the short stories; it partakes of something of both poetry and prose (one as imaginative journey and the other as investigating sides of the self). 6

The physical journey of Arthur Gordon Pym in the narrative parallels, to some extent, the intellectual journey of Poe to the cosmic system he envisioned in Eureka near the end of his life. ${ }^{7}$ There is an evolutionary quality even within the narrative in that it progresses from what at first seems a realistic tale of the sea to what later becomes a treatment of the deeper and more serious subject of the destiny of man. What began as an elaborate literary hoax became, in fact, one of Poe's most important fictional treatments of the relationship between man and God and the universe. As one comes to realize that Pym is not simply a highly imaginative story of a sea voyage but is a symbolic voyage of the mind, he comes closer to understanding its

6Poe, A Critical Study, p. 157. Patrick Quinn nearly echoes Davidson's view: "Specifically, it possesses the additional interest of furnishing the reader of Poe with a wrprisingly complete account of his principal themes... the one central and focusing story in the entirety of Poe's work." The French Face of Edgar Poe, p. 193.

7

Harry Levin recognizes a similarity between Poe and Pym: "If he does not speak in his own person, he has a perfect surrogate in his hero; and if their equivalence is not fully attested by the rhythmic equation between Edgar Allan Poe and Arthur Gordon Pym, it is underlined by Pym's family connections with... Edgartown." The Power of Blackness (New York, 1958), p. 110 . 
real importance as an integral part of Poe's developing oodmic theories. Davidson writes of Pyn's (and Poe's) journey to cosmic consciousness:

...irresolute as the book is, it is a study of emerging consciousness, a very special intelligence and awareness which is Arthur Gordon Pym's (and, to an extent, Poe's).... Poe steadily defines and sharpens the point of perception until all else fades before the intensity with which a Pym-self regards the world and itself.... However ill-organized it may be, Pym is a study of the emergence and growth of the knowing and thinking self. Though Poe wrote other inquiries into this subject, he never made quite so complete an investigation as he did in this sustained narrative. 8

In his lengthy analysis of Pym in The French Face of Edgar Poe, Patrick Quinn finds several recurring themes weaving throughout the narrative to form a pattern, which, when viewed in its entirety, can be interpreted as a fictional representation of $\mathrm{Poe}^{\prime}$ s cosmic design. The themes of revolt, deception, premature burial, and perverseness, though treated to some extent in many works before and after Pym, combine in this work, following Gordon Pym's journey from Nantucket to nirvana. 9

The directness of the opening sentence of the narrative is echoed years later in another symbolic voyage, Mel-

${ }^{8}$ Poe, A Critical Study, pp. 160-161. Patrick Quinn mites of Poe's imaginary voyage: "...it is a narrative of exploration; things are to be found out and clarified.... the ovement is characteristically from darkness to light, upward, from mystery to clarity." p. 199.

$$
{ }^{9} \text { P. Quinn, pp. 169-205. }
$$


Ville's Moby Dick: "My name is Arthur Gordon Pym."10 Very arly in his story, Pym confesses a growing attraction to the sea, the result of his friend's repeated "stories of the natives of the Island of Tinian, and other places he had visited in his travels" (pp. 5-6). He writes later: "At last I could not help being interested in what he said, and by degrees I felt the greatest desire to go to sea" (p. 6). But, instead of steming from a natural youthful curiosity to explore the romantic possibilities of ocean travel and its consequent adventure, Pym is motivated by an admitted perversity:

My visions were of shipwreck and famine; of death or captivity among barbarian hordes; of a lifetime dragged out in sorrow and tears, upon some gray and desolate rock, in an ocean unapproachable and unknown. Such visions or desires--for they amounted to desires-are common, I have since been assured, to the whole numerous race of the melancholy among men--at the time of which I speak I regarded them only as prophetic glimpses of a destiny which I felt myself in a measure bound to fulfill. 11

The prelude to Pym.'s long voyage is a very short but, nonetheless, nearly disastrous one, during which he and his

${ }^{10} \mathrm{p}$ : 5. Patrick Quinn offers a convineing argument for Melville's debt to Poe in The French Face of Edgar Poe, pp. 205-215.

11 pp. 17-18. For interesting discussions of Poe's treatment of perversity in his works, see D. H. Lawrence, "gigar Allan Poe," Studies in Classic American Literature (New York, 1953), pp. 73-92; Marie Bonaparte, The Life and Norks of Edgar Alian Poe, tr. John Rodker (London, 1949), pp. 62-64; and D. M. Rein, Edgar Allan Poe, The Inner Pattern (New York, 1960), Pp. 31-32. 
friend, Augustus, barely escape destruction. Retiring after a late party, during which both boys become intoxicated, Mugustus, feigning sobriety, convinces Pym to "go out on a frolic with the boat." During the ill-fated venture, Augustus loses control by degrees to the wine he had drunk and finally collapses in the bottom of the small boat, leaving Pyw helpless and terrified in the stormy seas: "I recommended myself to God, and made up my mind to bear whatever aight happen with all the fortitude in my power. Hardly had I come to this resolution when, suddenly, a loud scream or rell, as if from the throats of a thousand demons, seemed to pervade the whole atmosphere around and above the boat" (p. 10).

The Ariel is run down by the whaler, Penquin, the source of the screams heard by Pym being the futile warning of its crew. The boys are miraculously rescued, after which Pym reacts to his "good fortune": "...our deliverance seemed to have been brought about by two of those almost inconceivable pieces of good fortune which are attributed by the wise and pious to the special interference of Providence" (p. 12).

From this point in the narrative through to its conelusion, if Providence interferes with Pym's life, it does so in an effort to bring him ever closer to an awareness of its apecial design. For the brief journey of the Ariel is merely a reflection in miniature of the longer journey which is to follow, and the sequence of experiences in the first vill closely parallel those in the second. The terror of 
and resignation to the imminent catastrophic destruction, the scream before the end, and the lapse into a state of enconsciousness will all be repeated and magnified as Pym draws closer to the awful truth of human existence. 12

Since his earliest poetry of the $1820^{\prime} \mathrm{s}$, Poe had explored the nature of reality, and, through this date, it seems to have continued to occupy no small part of his considerations. In Pym we are constantly made aware of the ambiguity of assumed reality by repeated deceptions of appearances. Pym indicates his own awareness of the tension between reality and appearance when he considers his recent escape from death:

In no affairs of mere prejudice, pro or con, do we deduce inferences with entire certainty even from the most simple data. It might be supposed that a catastrophe such as I have just related would have effectually cooled my incipient passion for the sea. On the contrary, I never experienced a more ardent longing for the wild adventures incident to the life of a navigator than within a week after our miraculous deliverance. ( $p .17$ )

Eighteen months later, when Augustus' father is about to embark on a whaling voyage as captain of the brig Grampus, Pym is urged by his companion to take advantage of the oppor-

12Davidson divides Pym into five parts: The Ariel episode; Pym's experiences in the hold; the overthrow of the of theers; the sufferings of the four survivors on the wreck of the Grampus; and the journey of the Jane Guy southward. of the se he writes: "Each of the four main narrative epirodes in Pym is...a development of a theme suggestively treated in that night's adventure aboard the Ariel...." Poe, oritical study, p. 164 . 
tunity to go to sea. And so begins a rapid succession of deceptions: After proposing the voyage to his parents, Pym's mother becomes hysterical and his grandfather threatens to cut off his inheritance. So he pretends to abandon the idea, while he and Augustus plan further deceptions. Deciding that Pym will stow away, Augustus forges a letter to Pym's father from a relative, inviting Pym to visit New Bedford for a fortnight, and later, disguised as a seaman, Pym heads for the hiding place prepared by Augustus in the Grampus.

Appearances continue to deceive as Pym is met and recognized by his grandfather on the way to the ship but is successful, through a convincing performance as a sailor, in persuading the old man that his name "bee'nt nothing at all like Goddin." Once aboard the ship Pym is impressed with the unusual comfort of the cabin, as Augustus leads him to the entrance of his hiding place in the hold. Goncealed by a carpet, the opening in the floor of the stateroom leads to a small but apparently comfortable "ironbound box":

It was nearly four feet high, and full six long, but very narrow... one of the ends of the box could be removed at pleasure.....A mattress from one of the cabin berths covered the whole of its bottom, and it contained almost every article of mere comfort which could be crowded into so small a space, allowing me, at the same time, sufficient room for my accomodation, either in a sitting position or lying at full length.... I proceeded immediately to take possession of my little apartment, and this with feelings of higher satisfaction, I am sure, than any monarch ever experienced upon entering a new palace. (pp. 23-24) 
Pym at once deceives and is deceived. The temporary oonfort of the "little apartment" disguises its coffin-like appearance, and Pym's excitement blinds him to its obvious dangers. Promising to return as soon as possible, Augustus leaves him in the darkness of the hold, introducing one of the major symbols of the book: blackness. ${ }^{13}$ Everything mrrounding Pym's temporary concealment seems to suggest a symbolic death, an escape from the world of consciousness into the realm of sub-conscious experience. It is Poe's dream-state through which it is possible to catch a fleeting glimpse of the ultimate reality which is God. ${ }^{14}$ Much like Mark Twain's Huckleberry Finn, who had to symbolically die before his journey down the Mississippi, Pym passes into that state, at first through his disguise, and later through his entrance into the darkness of the coffin-like box. ${ }^{15}$

${ }^{13}$ Leslie Fiedler presents an interesting interpretation of Pym as a novel of the American south: "...its subject is slavery....Poe's novel is surely the first which uses gothicism to express a peculiarly American dilemma identifying the symbolic blackness of terror with the blackness of the Negro and the white guilts he embodies." "The Blackness of Darkness: The Negro and the Development of American Gothic," Images of the Negro in American Literature, ed. Seymour Gross and John Hardy (Chicago, 1966), p. 85. For a similar view, see Harry Levin, The Power of Blackness (New York, 1958), pp. 120-124.

${ }^{14}$ In Poe's later tales, such as "Mesmeric Revelations" and the colloquys, he identifys the hypnotic state produced by mesmerism as one condition through which man can reach the truth of his existence. He had, of course, treated a *imilar experience in his early poetry.

15

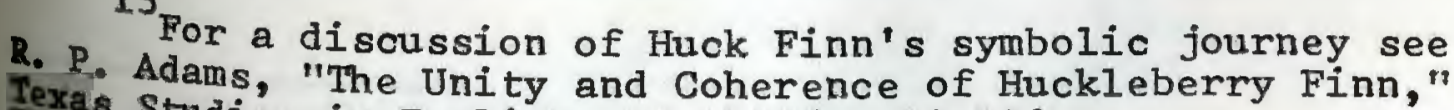
Texas Studies in English, VI (1956), 87-103. 
From this blackness of nonexistence and intellectual darkness, Pym must emerge, reborn, to begin his journey to cosmic consciousness.

The original plan for Pym's voyage in his agreement With Augustus called for his removal from the hold once the Grampus was far enough out to sea to discourage Captain larnard's turning back. However, the paths of revolt and deception cross again, as the crew rebels, making it imposvible for Augustus to reveal Pym, who spends eleven days in a state of increasing agony and terror. When Augustus is himself imprisoned in the steerage, it appears that Pym's rescue is hopeless. But as Patrick Quinn writes: "In the desperate career of Gordon Pym the apparent and the actual rarely coincide. And so it is just because he is a prisoner himself that Augustus soon finds it possible to rescue Pym from the hold. ${ }^{16}$

Before his rescue from his hiding place in the hold, however, Pym undergoes a series of experiences which indicates the ambiguity of assumed reality and draws him deeper into a state of despair. His early enthusiasm gradually disappears as first he discovers some of his food "in a state of absolute putrefaction," and later, after sleeping "for an inordinately long period of time" he finds himself "trangely confused in mind" and quite ill. In the growing atench of the hold, suffering from thirst and near-delirium, 
pym falls "into a state of profound sleep," during which he dreams of demons, serpents, and a fierce lion, from whose throat bursts "a roar like the thunder of the firmament." When he awakens from this dream within a dream, he realizes that it was not completely an illusion: "My dream, then, was not all a dream. Now, at least, I was in possession of my senses. The paws of some huge and real monster were pressing heavily upon my bosom--his hot breath was in my ear--and his wite and ghastly fangs were gleaming upon me through the gloom." 17

After passing through a state of terror, during which he resigns himself to death, he becomes aware of the deception and recognizes "the peculiar whine of my Newfoundland dog, Tiger." But he is deceived again, for the dog is at first a source of comfort and later one of horror, as he becomes mad and lunges at his master's throat. Pym is himself bordering on madness as his confinement becomes more unbearable and he becomes feverish:

As upon a former occasion, my conceptions were in a state of the greatest indistinctness and confusion after leaving the mattress.... I had slept as before, for a very long period of time....I was burn-

17p. 25. Patrick Quinn writes of this and similar pasrages: "The images of dream and waking life become inextrieable confused..... Behind the straightforward...prose...there is a potent dream symbolism at work.... in which the movement l....going downward... from twilight into mystery and darkof Ar. pp. 190, 200. W. E. Benzanson, "The Troubled Sleep 1. Arthur Gordon Pym," Essays in Literary Hi story Presented to Is M Iton French, (New Brunswick, N. J., 1960), pp. 149-175, similar discussion worth noting. 
ing up with fever, and my thirst was almost intolerable.... I was feeble in the extreme--so much so that I shook all over, as with an ague, at the slightest movement or exertion....I would remain for some minutes in a state bordering on insensibility. (pp. 2931)

He later attempts to work his way back to the opening in the floor of Augustus' room, using the rope strung out for that purpose, but finds the trap impossible to open. His reaction to his present condition repeats a major theme of the book:

My sensations were those of extreme horror and dismay. In vain I attempted to reason on the probable cause of my being thus entombed. I could summon up no connected chain of reflection, and, sinking on the floor, gave way, unresistingly, to the most gloomy imaginings, in which the dreadful deaths of thirst, famine, suffocation, and premature interment, crowded upon me as the prominent disasters to be encountered. (p. 33)

After regaining some semblance of composure, Pym returns to his hiding place and discovers a slip of paper attached to Tiger, which he determines to be a note from Augustus. Now without candles, he decides to use the remaining phosphorus to read the note, but discovers a blank sheet, which he tears to pieces in anger. He later realizes his mistake in seeing only one side of the sheet and manages to retrievenough pieces to discern a fragment of the message: Mlood--your life depends on lying close" (p. 4l).

Although incomplete, the message leaves Pym without hope, his terrified condition later worsened by his dog's mad attack. He finds himself unable to return to his meager 
provisions in the box, having had to lock the dog inside, and submits to a perverse desire:

I now found my whole stock of provisions reduced to a single gill of liqueur. As this reflection crossed my mind, I felt myself actuated by one of those fits of perverseness which might be supposed to influence a spoiled child in similar circumstances, and, raising the bottle to my lips, I drained it to the last drop, and dashed it furiousily upon the floor. (p. 44)

The apparently hopeless situation becomes hopeful, as Pym hears a voice in the distance which he assumes to be Augustus'. Hope turns into despair when he is unable to answer the voice and it begins to fade away:

The sound presently grew less distinct, then again less so, and still less. Shall I ever forget my feelings at this moment? He was going--my friend--my companion, from whom I had a right to expect so much--he was gone: He would leave me to perish miserably, to expire in the most horrible and loathsome of dungeons--and one word--one little syllable would save me--yet that single syllable I could not utter? (p. 45)

But appearances and reality shift so often and rapidly in this narrative, that it is impossible to anticipate anything and equally impossible to completely believe the description of an incident when it does happen. Seemingly utterly and completely hopeless, Pym's situation changes again as he accidentally falls, dropping a knife "with a rattling sound to the floor." The question of his fate in the hold is resolved as Augustus appears with food and water and tells him what has occurred on board since he saw him last. 
The treachery of the revolt which has passed is repeated as Augustus and Peters, with the aid of Pym, plan to averthrow the mutineers. The success of the plan depends on another deception. Pym is to appear before the drunken men made up to look like the horribly deformed corpse of the poisoned sailor, Rogers. Pym's reaction to his disguise indicates the extent to which even he is uncertain of the reality of his appearance:

As I viewed myself in a fragment of looking glass which hung up in the cabin, and by the dim light of a kind of battle lantern, I was so impressed with a sense of vague awe at my appearance, and at the recollection of the terrific reality which I was thus representing, that I was seized with a violent tremor, and could scarcely summon resolution to go on with my part. It was necessary, however, to act with decision, and Peters and myself went up on deck. (p. 88)

The disguise works, and the ship is taken, but the success is only apparent as the Grampus is soon overtaken by a storm and is left a nearly completely submerged hulk. The four survivors; Pym, Augustus, Peters, and Parker, lashed to the windlass, ride out the storm only to recognize that they "had escaped the less dreadful perils of the sea" (p. 105). Without sufficient provisions, despite repeated attempts at diving into the hold, the men resign themselves to what is apparently their doom.

The tension between appearance and reality continues as a major theme of the narrative with two false rescues of the survivors of the Grampus. They first encounter a black Dutch ship, which, sailing towards them, gives them great 
hope, until they realize that all aboard are dead. A sound, "resembling the scream of a human voice," is really the gereech of a seagull, which has gorged itself on the flesh of a dead sailor:

As the brig moved further round so as to bring us close in view, the bird, with much apparent difficulty, drew out its crimsoned head, and, after eyeing us for a moment as if stupefied, arose lazily from the body upon which it had been feasting, and, flying directly above our deck, hovered there a while with a portion of clotted and liverlike substance in its beak. The horrid morsel dropped at length with a sullen splash immediately at the feet of Parker. (pp. 112-113)

The death ship passes, and, sometime later, another appears, creating temporary "extravagant demonstrations of joy." But the results of this apparent rescue are the same as those of the earlier appearance of the Dutch ship. Pym writes:

I was so affected by their conduct, as well as by what I now considered a sure prospect of deliverance, that I could not refrain from joining in with their madness, and gave way to the impulse of my gratitude and ecstasy by lying and rolling on the deck, clapping my hands, shouting, and other similar acts, until I was suddenly called to my recollection, and once more to the extreme of human misery and despair, by perceiving the ship all at once with her stern fully presented towards us, and steering in a direction nearly opposite to that in which I had at first perceived her. (p. 122)

Faced with the prospect of starvation, the men resort to cannibalism, at the suggestion of Parker, who, ironically, becomes the victim. They are later able to procure some food from the hold, but Augustus dies, finally, from a wound received in overtaking the mutineers. The supply of food is 
lost as the brig turns over, in what at first seems an accident surely to result in the deaths of Pym and Peters. However, once again the appearance is not the reality:

...we found the whole bottom...thickly covered with large barnacles, which proved to be excellent and highly nutritious food. Thus, in two important respects, the accident we had so greatly dreaded proved a benefit rather than an injury; it had opened to us a supply of provisions which we could not have exhausted, using it moderately, in a month; and it had greatly contributed to our comfort as regards position, we being much more at our ease, and in infinitely less danger, than before. (p. 144)

Several days later a third ship appears, and, although at first it seems the results of the earlier two appearances will be repeated, the Jane Guy turns out to be, in reality, a rescue ship:

We now became alarmed, for we could hardly imagine it possible that she did not observe us, and were apprehensive that she meant to leave us to perish as we were--.... In this instance, however, by the mercy of God, we were destined to be most happily deceived... the stranger, who immediately afterward ran up a British flag, and, hauling the wind, bore up directly upon us. In half an hour more, we found ourselves in her cabin. (pp. 146-147)

Aboard the Jane Guy, Pym looks back on his experiences without complete recollection, as though he had just awakened from a frightful nightmare from which can be remembered the horror but not the incidents: "...both Peters and myself recovered entirely from the effects of our late privation and dreadful suffering, and we began to remember what had passed rather as a frightful dream from which we had been 
happily awakened, than as events which had taken place in sober and naked reality" (p. 150).

The ship continues to sail south, and, although not his original plan, Captain Guy is persuaded by Pym to push further south in an effort to discover new lands. Patrick Quinn writes that "Pym's will-to-disaster asserts itself" as he urges the captain "farther into the unknown south."18 Poe's symbolic use of color resumes first with the appearance of a strange white animal with red teeth and claws and later with the discovery of the island of Tsalal, a black island peopled by black natives. Charles $0^{\prime}$ Donnell draws a significant parallel between the contrast of black and white in Pym and the forces responsible for the cosmic cycle which Poe later describes in Eureka:

All the characters, black and white alike simply wish to preserve their lives; they are human beings. But in one respect Pym differs from the savages whose principle of civilization is based on the struggle to survive in the primitive state of earthly life. Just as Poe embodies organic and inorganic in black and white, so is there in Pym's ambivalent feelings toward life and death a suggestion of the later repulsion-attraction idea. I9

Although they appear friendly, the natives kill all but Pym and Peters in a massive landslide. Pym's description of the disaster sets the tone for what is to come:

$$
18 \mathrm{p} \text {. Quinn, p. } 181 .
$$

19 "From Earth to Ether: Poe's Flight into Space," PMA, IXXXVII Earth to Ether: Po 
"I was suddenly aware of a concussion resembling nothing I had ever before experienced, and which impressed me with a vague conception, if indeed I then thought of anything, that the whole foundations of the solid globe were suddenly rent asunder, and that the day of universal dissolution was at hand" (p. 203).

After several days of wandering through the caves which saved them, Pym and Peters run for shore. The natives have destroyed the Jane Guy and all who remained aboard, but the two men are able to make their escape to the south in a native canoe with a captive named $\mathrm{Nu}-\mathrm{Nu}$. The sea becomes warm and milky as the black of Tsalal fades to a "gray vapor," which, in turn, becomes a white ash. The black NuMis reaction to the white around him parallels that of the sailor in "MS. Found in a Bottle," as he approached the ultimate truth: "he became violently affected with convulsions. These were succeeded by drowsiness and stupor" (p. 240).

Beyond the similarity of the endings in the se two works, there are others which seem to indicate that Pym is an enlargement of a pattern developed in that earlier shorter tale. Patrick Quinn writes of this relationship:

...the book as a whole recalls one of Poe's earliest creations, "MS. Found in a Bottle." In that story the narrator is rescued from shipwreck... is navigating in waters near the South Pole; and all the author can learn of its mission is that "we are hurrying onwards tossome exciting knowledge--some never-to-be imparted secret, whose attainment is destruction." like Gordon 

Pym, he feels no desire to turn away from the knowl-
edge or the destruction. 20

$\mathrm{Nu}$ - Nu dies from terror before the canoe vanishes into the cataract, while Pym and Peters face the blinding whiteness and destruction.

The summit of the cataract was utterly lost in the dimness and the distance. Yet we were evidently approaching it with a hideous velocity.... Many gigantic and pallidly white birds flew continuously now from beyond the veil, and their scream was the eternal Tekeli-li:... And now we rushed into the embraces of the cataract, where a chasm threw itself open to receive us. But there arose in our pathway a shrouded human figure, very far larger in its proportions than any dweller among men. And the hue of the skin of the figure was of the perfect whiteness of the snow.21

Although Poe may have intended that we believe Pym achieved at the end of his journey a vision of the desting of man, it seems fairly certain that neither the author nor the reader has reached a similar awareness. In fact, the ending is so vague and uncertain as to make any conclusion purely speculative. 22 However, the last lines of Poe's

20p. Quinn, pp. 194-196.

${ }^{21}$ pp. 241-242. Malcolm Cowley writes generally of Pym and specifically of this passage: "...Pym... is Poes's longest story and which, though hastily written, ends with the finest passage in all his works." "Aidgarpo," New Republic, V (November, 1945), p. 610 .

22

Jules Verne in a much later novel, Sphinx des Glaces, wrote what Frances Winwar calls "at once a sequel to Poe's narrative and a solution of Pym's mysterious end." The Haunted Palace, p. 190. Marie Bonaparte, in her psychoanalytic interpretation of Poe's works, interprets the ending of Pym as "return-to-the womb." pp. 290-352. 
final note to the work, a translation of the "Ethiopian characters so mysteriously written" in the caves of Tsalal, may provide some clue to the whiteness of Pym's vision: "I have graven it within the hills, and $m y$ vengeance upon the dust within the rock" (p. 245). Sidney Kaplan writes of

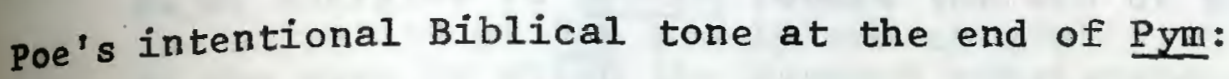

The passage, quoted, sounds as if it comes from Scripture; in fact, it was written by Poe, who, in another tale, would engrave on an African stone the words "DESOLATION" and "SILENCE." The "I" in the passage is the "human figure" of the chasm. Both are Jehovah, who also not rarely wrote his word on stone.... It was the "will of God" that Poe tried to present in his allegory of black and white at the end of Pym. 23

If Poe meant to convey the conclusion that the inevitable destruction of man is the will of God, it appears that his vision of that force was less spiritual than physical. Pym's voyage occasionally takes on the appearance of a dream, but it is most often solidly based in the world of physical reality. However, that world is represented as ambiguous and confused, unpredictable and terrifying; and always on the verge of destruction. Although the answers to the many questions raised in Pym are few, one important conclusion Poe seems to have reached is that what appears to be physical reality is capable of instantaneous disintegration, a

${ }^{23}$ Kaplan, pp. xxii, xxv. In the same "Introduction," Kaplan writes: "Revelation is precisely what Poe is after.... it may come as a surpríse that Poe was a Biblical fundamentalist of the most orthodox sort." p. xxiii. 
theme traceable through most of his works and which constitutes one of the unifying threads in the evolutionary pattern of his Cosmic Myth. Davidson writes:

This theme might be called the cheating deceptiveness of reality, a subject on which he would expend his major energies in Eureka toward the end of his life. The narrative of Pym slowly and carefully reveals to us the ways by which the assumed consistency, trustworthiness, the very reality of the world and of men are capable, on the instant, of disinfegrating, dissolving, or becoming a mere illusion. ${ }^{2}$

The most significant aspect of the whiteness which awaits Pym at the end of his journey is that it appears to be symbolic of a type of unity which Poe treated as part of the cosmic cycle in Eureka. As Pym passes from Nantucket to the South Pole, he gradually loses an awareness of his individual identity until, at the end, he vanishes in to the cataract. Davidson writes of Pym's loss of identity:

The journey is a study in the depersonalization of the self...along that journey, others, like the powerful Dirk Peters, lose their identity and, like Pym, pass from the positive, assertive self to the lost or indeterminate self. As we approach the eschatos toward which Pym is driven, everything tends to blend and to go back toward first principles or become colorless, bland, shapeless, even mindless..... In destruction there is knowledge; in loss there is gain.... the hero finds himself only at the moment he loses himself; he dies the instant he is about to be born again; the blankness of eternal mystery engulfs him the moment he faces the white light of revelation. 25

\footnotetext{
24"Introduction," Seledted Writings of Edgar Allan Poe, pp. xxi-xxiii.

25

Poe, A Critical Study, pp. 176-177.
} 
There are at work in Pym two opposing forces, very much related to $\mathrm{Poe}^{\prime}$ s later reduction of all matter to the forces of attraction and repulsion in Eureka. On the one hand, Pym is terrified in the flux of his environment, and, on the other, he is overtaken by the desire to continue his journey. O'Donnell writes of this conflict and its concluding whiteness:

The essential dilemma of man's existence is defined by the principle of attraction-repulsion--hence the unfolding-infolding, the quest for cosmic unity and the terror of annihilation.... In Pym we see the dramatization in metaphor and symbol of the core idea that Poe later expressed as abstract principle. The unfolding dread of annihilation and the unfolding search for unity....control the method of the novel.... Let us assume... that Poe meant the South Pole, to suggest the perfect unity, the full design.... White, the "omnicolor" as Poe calls it elsewhere, is the perfect blend of all colors, and broken up it becomes the separate colors, just as God broke up the unity of unparticled matter into the disunity of particled matter, which then struggles again toward reunification with the full design. The separate colors, the disparate elements, struggle to achieve the perfect condition of white, to blend into unity. 26

Another aspect of the duality in Pym is that of the relationship between imagination and reason, which later becomes a significant element of Poe's developing cosmic concepts. Patrick Quinn writes:

26"From Earth to Ether," pp. 86,87. O'Donnell draws an even more direct parallel between Pym and Eureka in that same article: "... whether the mode is esthetic or philosophical, the idea that shapes the work is fixed; it is therefore not really foolhardy to ignore the demands of chronology, to act as though an ambidextrous Poe had simultaneously written Pym with one hand and Eureka with the other. " p. 86 . 
Thus of all the work of Poe, Arthur Gordon Pym is the crucial text because it provides on a large scale an exercise in understanding Poe's characteristic methods. Through a study of this book one learns how Poe should be read....here... we find reflected the two major aspects of Poe's mind, the one obscure in the dark torment of nightmare, the other lucid and enquiring, and eager to explain (all too expansively at times) real and concrete matters of a thoroughly prosaic kind. 27

The most important works related to $\mathrm{Poe}^{\prime} \mathrm{s}$ evolving myth which come after Pym will be more explicit expressions of his conclusions on the order of the universe and man's place in it. In the tales and essays of the $1840^{\prime} \mathrm{s}$, the symbols of Poe's journey will give way to direct expressions of his personal cosmic theories, as he prepares to write his final words on the subject in Eureka. 
IV. IATER TALES: CONVERSATION, GOLLOQUY AND COLIAPSE

In The Narrative of Arthur Gordon Pym and the earlier tales, Poe had symbolically treated, to varying degrees, many of the aspects of his final cosmic vision described in gureka. From "Metzengerstein" in 1832 through Pym in 1838, it appears possible to trace Poe's growing awareness of a universal pattern as well as his increasing ability and determination to express that awareness in his tales. However, that expression in the early works is as fragmentary as it is symbolic, since Poe presents in that fiction several parts of but never his camplete cosmic vision. In "The Fall of the House of Usher," he comes as close to a symbolic micro-cosmic presentation of his total concepts, al though concentrating on the last stages of the cosmic cycle, as he has in any of his fiction to that date.

"The Fall of the House of Usher" was first published in Mrton's Gentleman's Magazine on September 18, 1839, and has since become one of Poe's most thoroughly analyzed stories. ${ }^{1}$ Contemporary opinion of the tale seems to have

${ }^{1}$ In The Mind of Poe and Other Studies, Killis Campbell concludes that for "The Hall of the House of Usher, "there 1s...little occasion to look for a source outside of Poe's own fancy." (New York, 1933), P. 176. However, Hervey Allen 
been favorable, and, in an 1839 letter to Philip Cooke, Poe indicated his pleasure with the reaction of another famous nineteenth century writer: "Beside me is now lying a letter from Washington Irving in which he speaks with enthusiasm of a late tale of mine, "The Fall of the House of Usher: "w2 poe himself counted it among his eight best tales. ${ }^{3}$ More recently, E. H. Davidson expresses a somewhat guarded judgment that the tale "is perhaps Poe's finest," 4 while Eric Carlson is more emphatic in his opinion that it "is undoubtedly Poe's greatest story. " 5

takes the position that Poe "and the strange conditions of his marriage are in part the subjects of the story and the poem...." Israfel, p. 357 .

20strom, I, p. 118. See L. F. Tasistro's praise of this tale originally published in the New York Mirror, December 28, 1839, and reprinted in The Recognition of Edgar Poe, ed. Eric W. Carlson, (Ann Arbor, Mich., 1966), p. 4.

${ }^{3}$ See f.n. 26, Chapter II of this paper. For further discussion and interpretation of "Usher" see Darrell Abel, "A Key to the House of Usher," University of Toronto Quarterly, XVIII (1949), 176-185; Leo Spitzer, "A Re-interpretation of "The Fall of the House of Usher?" Comparative Literature, IV (January, 1937), 379-401; H. R. Warfel, "Poe's Dr. Percival: A Note on 'The Fall of the House of Usher"," Modern Language Notes, LIV (February, 1939), $129-$ 131; I vor Winters, "E. A. Poe: A Crisis in the History of American Obscurantism," American Literature, VIII (January, 1937), 379-401; Allen Tate, "Three Commentaries: Poe, James, and Joyce," Sewanee Review, LVIII (January-March, 1950), 1-4; and A. H. Marks, Two Rodericks and Two Worms: 'Egotism; Or, The Boston Serpent'," PMLA, LXXIV (December, 1959), $607-612$.

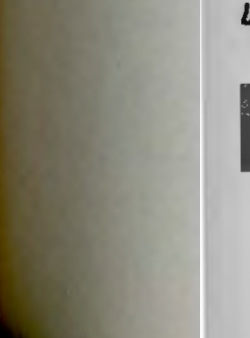

Selected Writings of Edgar Allan Poe, p. 500. troduction to Poe, p. 578. 
However, the significance of this tale here rests not with its comparative literary value but with its place in the evolutionary pattern of Poe's Cosmic Myth. While we are taken on a rather extended symbolic voyage of the mind in wich the fragmentary cosmic themes used by Poe to that date seem to converge, "The Fall of the House of Usher," by its very conciseness and equally thorough treatment of those themes, appears to be a more direct and explicit expression of essentially the same aspects of Poe's total view of the cosmic cycle. One of the phases of this cycle as expressed in Bureka is the return of all matter in the universe to the unity of the single original particle which is God, and out of which will be created through irradiation a new universe. The House of Usher, both the physical building and the family which inhabits it, can be viewed as a micro-cosmic representation of Poe's "universe of stars," outside of which may exist other similarly limited universes. Maurice Beebe writes of this theme in "Usher":

In the ideal short story, like the universe, everything is related and nothing is irrelevant." "The Fall of the House of Usher"... is a nearly perfect illustration of $\mathrm{Poe}^{\text {'s }}$ theory of totality....

The House of Usher is like the universe not only in that everything is related but also in that it is limited. In Eureka Poe insists that the universe we know is not infinite and that there may be many neighboring universes each with its own god. As a result, our universe could conceivably be entered and left again. The same is true of the house of Usher.... 
The emphasis on the isolation of the house of Usher helps the 6 impression of a self-contained world, a totality. 6

Drawn to "the melancholy House of Usher" by a letter from Roderick indicating the latter's pathetic state of physical and mental suffering, the narrator, "with a view of attempting...some alleviation of his malady," approaches the Usher property. As he views the scene before him "with an utter depression of soul," he describes its physical characteristics:

I looked upon...the mere house, and the simple landscape features of the domain--upon the bleak walls-upon the vacant eye-like windows--upon a few rank sedges--and upon a few white trunks of decayed trees.... I scanned more narrowly the real aspect of the building. Its principal feature seemed to be that of an excessive antiquity. The discoloration of ages had been great. Minute fungi overspread the whole exterior, hanging in a fine tangled web-work from the eaves.... Perhaps the eye of a scrutinizing observer might have discovered a barely perceptible fissure, which, extending from the roof of the building in front, made its way down the wall in a zigzag direction, until it became lost in the sullen waters of the tarn. (III, 273, 276-277)

As the story progresses, we begin to realize the significance of the appearance of the house, as it mirrors the appearance and condition of its inhabitants, particularly

6"The Universe of Roderick Usher," Poe, A Collection of Critical Essays, ed. Robert Regan (Inglewood Cliffs, N. J. 1967), p. 121. In Eureka Poe concludes with a description of this totality of life: "... bear in mind that all is Life--Life--Life within Life-- the less within the greater, and all within the Spirit Divine" (XVI, p. 315). 
Roderick. The house and family are both ancient and appear to be on the brink of disintegration. The facade of the house with its eye-like windows, web-work of fungi hanging from the eaves, mouth-like door, and "barely perceptible fissure" is the face of Roderick personified:

...the character of his face had been at all times remarkable. A cadaverousness of complexion; an eye large, liquid, and luminous beyond comparison; lips somewhat thin and very pallid... hair of a more than web-like softness and tenuity.... The now ghastly pallor of the skin and the now miraculous lustre of the eye, above all things startled and even awed me. The silken hair, too, had been suffered to grow all unheeded, and as, in its wild gossamer texture, it floated rather than fell about the face. 7

Usher's mental condition is described as a feeble and futile struggle to overcome a state of "excessive nervous agitation." His senses are so acute that he could eat only "the most insipid food," endure only the mildest of odor, light, and sound, and "wear only garments of a certain texture." 8 He ascribes his condition to "an influence... of his

7III, 278-279. Richard Wilbur writes of this personification: "The House of Usher is, in allegorical fact, the physical body of Roderick Usher, and its dim interior is, in fact, Roderick Usher's visionary mind." "The House of Poe," Poe, A Collection of Critical Essays, p. 107. Stephen Mooney takes a larger view: "The House is man personified." "Poe's Gothic Wasteland," The Recognition of Poe, p. 278. In Israfel, HHervey Állen recognizes Poe in Roderick: "The description of Roderick Usher is the most perfect pen-portrait of Poe himself which is known." p. 357 .

${ }^{8}$ This description of Usher's physical limitations is interpreted by J. O. Bailey as a characteristic of vampirism. "What Happens in "The Fall of the House of Usher'?" American Literature, XXV (January, 1964), 445-466. For further discussions of vampirism in Usher, see Lyle Kendall, "The Vam-
culd 
family mansion...over his spirit" and "to the severe and long-continued illness--indeed to the evidently approaching dissolution" of his sister, Madeline. 9 However, there is at least some evidence in these passages to suggest that the struggle which is taking place in Usher's universe is the result of the two forces responsible for the cycle of birth, life, death, and rebirth of the universe in Eureka: attraction and repulsion. Maurice Beebe writes:

In "The Fall of the House of Usher," one of... Poe's novel universes contained within a larger universe, the chain of radiation and contraction extends circle-like, from the tarn to the house to Roderick to Madeline to Roderick to the house to the tarn. Roderick is the dramatic center of the story and, like the atoms in Eureka, both agent and object.10

Roderick appears to be struggling against the inevitable collapse of his universe, as all material existences within it, both animate and inanimate, are slowly giving way to the unifying force of attraction. As this force increases, he recognizes the increased sentience, not only his own, but also that of the very house around him. Of this condition of Usher's intensified perception and the sentience of the house, E. Arthur Robinson writes:

pire Motif in 'The Fall of the House of Usher', "College English, XXIV (March, 1963), 450-453 and D. H.' Lawrence, Studies in Classic American Literature, pp. 73-92.

${ }^{9}$ III, 281. David M. Rein writes that Usher's treatment of Madeline "expresses once again his (Poe's") hostility to Virginia." Edgar A. Poe, The Inner Pattern (New York, 1960), 74 .

10 "The Fall of the House of Pyncheon," Nineteenth Century Fiction, XI (July, 1956), p. 4. 
The correspondence between Usher and his house is now complete. Each has attained "sentience" beyond the customary allotment-- the house in acquiring any perceptible evidence of this quality and Usher in his intensified sensory powers and his morbid self-analysis and realization of consciousness. On their respective levels each is fully developed into a super-organism carrying within itself the causes of its own destruction. 11

One of the recurring themes in "The Fall of the House of Usher" is that of the duality of existences and occurrences, described by Patrick Quinn as the Doppelganger theme. 12 Maurice Beebe writes that "within the unity of the House of Usher are mirrored correspondences which represent the split between diffusion and contraction."13 When these dualities no longer exist, and the force of attraction overcomes the force of repulsion, then all matter will achieve its original unity. Roderick and Madeline join in an embrace of death; the raging storm outside and that within become one; the house sinks into its reflection in the tarn; and the house and its inhabitants become one in mutual and total destruction. Maurice Beebe writes of the balance between the two opposing forces:

As long as Roderick radiates the diffusing power symbolized by his artistic activities and the "Iuminousness" of his eyes, he is able to maintain a balance between himself and the elements which otherwise would return upon him--between, in other words,

$11^{\text {"Order }}$ and Sentience in "The Fall of the House of Usher'," PMLA, LXXVI (March, 1961), p. 73.

${ }^{12} \mathrm{P}$. Quinn, p. 237.

13"The Fall of the House of Pyncheon," p. 5. 
the forces of expansion and contraction. But... in time the diffusing agent becomes weakened, Roderick, himself seeking a return to oneness and the negation of tension, allows himself to become a passive prey to the "kingdom of inorganization."14

And so, after the narrator has "fled aghast," he turns to watch the final catastrophe:

The storm was still abroad in all its wrath.... Suddenly there shot along the path a wild light.... The radiance was that of the full, setting, and bloodred moon, which now shone vividly through that once barely discernible fissure.... While I gazed, this fissure rapidly widened--there came a fierce breath of the whirlwind--the entire orb of the satellite burst at once upon my sight--my brain reeled as I saw the mighty walls rushing asunder--there was a long tumultuous shouting sound like the voice of a thousand waters--and the deep and dank tarn at my feet closed sullenly and silently over the fragments of the "House of Usher."15

"The Fall of the House of Usher" is probably Poe's clearest narrative expression of the central conclusions in Eureka. The condition of Roderick Usher's universe in miniature appears to be representative of the last stages of the larger "universe of stars" in Eureka as it approaches unity in the single particle of matter. Carroll D. Laverty writes of the relationship of these two works: "The Fall of the House of Usher' portrays artistically the return of everything--The House of Usher--into nothingness just as the

\section{${ }^{14}$ Ibid.}

15III, 297. Patrick Quinn characterizes the narrator: "Usher's guest never penetrates beyond appearances; he lives this experience; its significance eludes him." p. 238. 
Universe, according to...Poe's statement in Eureka will ultimately dissolve into nothingness. "16

The difference here, of course, is that in "The Fall of the House of Usher," as in the earlier tales, there is no indication of the cycle of creation and destruction which Poe described in Eureka. We are left with the narrator at the point of destruction without hope for the future. E. Arthur Robinson writes of this void at the end of the tale: "Usher, either transitionally in Poe's thought or dramatically in the story, cannot see beyond his present destruction. His is the story of man's fall, and any emergence into a newly self-creative, expansive existence is left unexpressed." 17

In Poe's preparation for this ultimate statement of his Cosmic Myth in Eureka, two of his later tales stand out as significantly, indicative of his growing determination to make the expression of his developing awareness more explicit. In "The Conversation of Eiros and Charmion" (1839), and "The Colloquy of Monos and Una" (1841) the symbolic portrayal of the inevitable destruction of the universe in the

16'Poe's Conception of Incident and Tone in the Tale," Modern Philology, XII (1944), 228-240.

17 "Order and Sentience in "The Fall of the House of Usher'," P. 74. In his interpretation of "Usher" as an allegory of the mind, Richard Wilbur writes of the ending: "... When the House of Usher does fall, the story ends, as it must, because the mind, at the end of its inward journey, has plunged into the darkness of sleep." "The House of Poe," p. 109. 
early tales gives way to a more direct statement of the destiny of man and his material environment. It may be that while Poe's evolving cosmic consciousness began to lead him to a clearer view of the universal plan expressed in Eureka it also began to lead him to a greater confidence in sharing that view with the world.

First published in Burton's Magazine in December, 1839, "The Conversation of Eiros and Charmion" indicates the extent to which Poe was now willing to imply less and express more of his cosmic vision. In this work he treats both the destruction of the earth and the resulting after-life, through the point of view of Eiros, who has just entered that state beyond death following the enveloping of the earth in flame. This tale, the theme of which Carlson calls "basic to Poe's perspective," 18 is significant because, unlike the symbolic collapse of the world (or universe) in "The Fall of the House of Usher," its concern is with the destruction of the real world. As a point of transition in Poe's fictional treatment of his developing concepts, this tale might be considered the stage between the symbolic portrayal of universal destruction in the sea tales and "Usher" and the direct expression of the collapse of "the utmost conceivable expanse of space" in Eureka.

${ }^{18}$ Introduction to Poe, P. 581. 
"The Conversation of Eiros and Charmion" is a brief dialogue which takes place in Aidenn, a setting similar to that of Angelo and Ianthe in "Al Aaraaf" and later described in "Dream-Land" (1844) as "Out of Space--out of Time." Eiros has entered this state of being "ten earthly years" after Charmion; she through the destruction of the earth and he through natural death. Her first reaction to her new condition is significant, especially when Poè's earlier treatment of the dream-state is considered. She says, "This is indeed no dream!" And Charmion assures her: "Dreams are with us no More" (IV, 1). It appears simultaneously to be an attempt to establish credibility and the expression of a conviction. For the instrument of destruction in this tale, Poe turns to the Biblical prophesy of the great conflagration, an idea he had earlier treated symbolically in "Metzengerstein" (1832). 19 However, the terror evoked by the visions of death in that early tale has developed into a calm, rational discussion of man's destiny. Eiros explains to Charmion:

When you left us, men had agreed to understand those passages in the most holy writing which speak of the final destruction of all things by fire, as having reference to the orb of the earth alone. But in regard to the immediate agency of the ruin, speculation had been at fault from that epoch in astronomical knowledge in which the comets were divested of the terrors of Flame. (I V, 3)

${ }^{19}$ See f.n. 38, Chapter One and f.n. 23, Chapter Three of this paper. 
The scientific, rather than poetic, description of the earth's destruction which follows is a prelude to Poe's treatment of this inevitable fact in Eureka.

After Eiros describes the approaching comet as "a gigantic mantle of rare flame, extending from horizon to horizon," she discusses the characteristics of the earth's atmosphere and its mixture of oxygen and nitrogen:

oxygen, which was the principle of combustion, and the vehicle of heat, was absolutely necessary to the support of animal life..... Nitrogen, on the contrary, was incapable of supporting either animal life or flame... What would be the result of a total extraction of the nitrogen? A combustion irresistible, all-devouring, omniprevalent, immediate;--the entire fulfilment, in all their minute and terrible details, of the fiery and horror-inspiring denunciations of the prophecies of the Holy Book. (IV, 7-8)

The memory of the approaching comet and the resulting conflagration is painful for Eiros, but she manages to conclude the description of her unique experience: "Then let us bow down, Charmion, before the excessive majesty of the great God:--then, there came a shouting and pervading sound, as if from the mouth itself of HIM... the whole incumbent mass of ether...burst at once into....intense flame.... Thus ended all" (IV, 8).

In the evolution of Poe's vision of the cosmos, several aspects of this colloquy appear to be of major significance. Although its science is really pseudo-science, his treatment of it suggests an awareness of its value potential in understanding and articulating his theories. Also, the 
indication of the presence of $\mathrm{God}$ and His responsibility in the destruction, though not a transition, is part of the thread of an idea which seems to run throughout Poe's philosophical explorations. What appears most important in this work, however, is a concept which completes the cosmic cycle described in Eureka: rebirth. E. H. Davidson writes of this cycle and the relationship of its philosophical and scientific aspects:

"The Conversation of Eiros and Charmion"... is a continuation of this apocalyptic vision of what might happen to the physical and intellectual universe when it exists beyond horror, that is, when discontinuity and incoherence are constants rather than aberrations. What Poe has here attempted to do is to estabIish a historical and symbolic relationship between myth, or prophecy, and the scientifically known constitution of the universe.... There is, consequently, a demonstration of the universal law of both matter and being which functions from Unity to dispersal and back to Unity again. 20

Although by 1839 Poe had already treated in his poetry and fiction the basic elements of the cosmic cycle of "alternate dissolution and rejuvenescence," and had used science and pseudo-science to arrive at and explain some aspects of his conclusions, he was yet to discuss one most important characteristic of his investigations. On January 29, 1840, "Instinct vs. Reason--A Black Cat" appeared in Alexander's Weekly Messenger, and in that essay Poe identified the process through which he would ultimately reach his particular cosmic truths:

${ }^{20}$ Poe, A Critical Study, pp. 132-133. 
While the self-love and arrogance of man will persist in denying the reflective power to beasts... he yet perpetually finds himself involved in the paradox of decrying instinct as an inferior faculty, while he is forced to admit its infinite superiority, in a thousand cases, over the very reason which he claims exclusively as his own. Instinct, so far from being an inferior reason, is perhaps the most exalted intellect of all. It will appear to the true philosopher as the divine mind itself acting immediately upon its creatures.... The leading distinction between instinct and reason seems to be, that, while the one is infinitely the more exact, the more certain, and the more farseeing in its sphere of action--the sphere of action in the other is of the far wider extent.2I

What is instinct in animals is analagous to intuition or instinctive knowledge in man, and in the introductory paragraphs of "The Murders in the Rue Morgue," published in Graham's Magazine in April, 1841, Poe uses his narrator to defend intuition when used in combination with analysis as a legitimate method of arriving at truth. When analysis or the reasoning faculty is unable to penetrate a mystery, the mind must use the accumulated information as a kind of launching pad from which to take an "intuitive leap" toward the final solution. Truth; then, is the result of the use of reason on the lower levels of awareness, followed by the employment of intuition on the upper levels. Of Dupin's ability to arrive at truth in this way, the narrator says:

...I could not help remarking and admiring... a peculiar analytic ability in Dupin... . He boasted to me, with a low chuckling laugh, that most men, in respect to himself, wore windows in their bosoms, and was wont

\footnotetext{
II Introduction to Poe, ed. Eric W. Carlson (Glenview, III., 1967), pp. $338-539$.
} 
to follow up such assertions by direct and very startling proofs of his intimate knowledge of my own. His manner at these moments was frigid and abstract; his eyes were vacant in expression; while his voice, usually a rich tenor, rose into a treble which would have sounded petulantly but for the deliberateness and entire distinctness of the enunciation. Observing him in these moods, I often dwelt meditatively upon the old philosophy of the Bi-Part Soul, and amused myself with the fancy of a double Dupin--the creative and the resolvent. (IV, 152)

of the ratiocinative tales in general, Eric Carlson

writes:

In the detective stories, Dupin personifies the analyst as artist... these analytical tales represent through Dupin...the superiority of the poetic intellect over rational analysis. The introductory pages of "The Murders in the Rue Morgue" constitute an essay on analysis as an imaginative art, in contrast to logical analysis. Dupin's powers of mind are those of the seer, the suprarationalist...his supreme gift lies in his artistic or intuitive mode of thought, comparable to the "side-long way" of looking at a star in order to see it distinctly. In solving a case...he begins with the psychological, and proceeds from observation to make subtle inferences, so that when he takes the intuitive leap, he has already employed fact and reason. 22

In "The Colloquy of Monos and Una," published in Gra's Magazine in August, 1841, Poe continued his argument for the superiority of intuition and developed the concept of rebirth, treated earlier in "The Conversation of Eiros and

${ }^{22}$ Ibid., p. xxx. Patrick Quinn recognizes Poe in Dupin: "Dupin is Poe, the resolvent Poe, the Analyst...." p. 227. In Poe, A Critical study, Davidson draws a paraliel between the detective tales and Eureka: "...the tales of ratiocination... form a curious linkage between certain premises set forth in the allegorical tales and the ultimate summa in Greka. They were moral, philosophical, and as auto-biographical as poe ever became." 404-413. 
Charmion." In regard to intuition, Poe appears to be speaking through Monos, when the latter says of the world he once knew:

Occasionally the poetic intellect--that intellect which we now feel to have been the most exalted of all--since those truths to us were of the most enduring importance and could only be reached by that analogy which speaks in proof-tones to the imagination alone, and to the unaided reason bears no weight--occasionally did...proceed a step farther in the evolving of the vague idea of the philosophic, and find in the mystic parable that tells of the tree of knowledge.... a distinct intimation that knowledge was not meet for man in the infant condition of his soul. (IV, 202)

After discussing the degeneration of mankind, due to the ascendence of knowledge acquired through reason and man's disregard of his intuitive potential, Monos makes the plea: "But alas for the pure contemplative spirit and majestic intuition of Plato!" (IV, 204).

Part of Poe's final vision in Eureka involves the merging of all things, material and spiritual, into the homogeneity of a single atom, out of which will evolve a new universe. He wrote in his 1841 review of Macaulay's Critical and Miscellaneous Essays: "The only irrefutable argument in support of the soul:s immortality--or, rather, the only conclusive proof of man's alternate dissolution and rejuvenescence ad infinitum--is to be found in analogies deduced from the modern established theory of the nebular cosmogony" $(\mathrm{x}, 159-160)$. 
As the universe approaches the material and spiritual unity of the primordial particle as described in Eureka, inanimate objects acquire sentience and man's senses become more acute. Poe had earlier treated this concept in "The Fall of the House of Usher," and now, three years later, he develops it further, as Monos describes his passage from life through death to his ultimate rebirth:

My condition did not deprive me of sentience.... The senses were unusually active, al though eccentrically so--assuming often each other's functions at random. The taste and the smell were inextricably confounded and became one sentiment, abnormal and intense.... The eyelids, transparent and bloodless, offered no complete impediment to vision.... Yet... I appreciated it only as sound.... The hearing at the same time, although excited in degree, was not irregular in precision, not less than of sensibility. Touch had undergone a modification more peculiar. Its impressions were tardily received, but pertinaciously retained, and resulted always in the highest physical pleasure....All my perceptions were purely sensual....

And now, from the wreck and the chaos of the usual senses, there appeared to have arisen within me a sixth all perfect..... And this--this keen, perfect, self-existing sentiment of duration--this sentiment existing (as man could not possibly have conceived it to exist) independently of any succession of events-this idea--this sixth sense, upspringing from the ashes of the rest, was the first obvious and certain step of the intemporal soul upon the threshold of the temporal Eternity. (IV, 206-207, 209)

Regarding Poe's treatment of the concept of rebirth,

A. H. Quinn writes:

"Monos and Una"... avoids that absurdity into which nearly all descriptions of the after life have fallen. Poe does not carry over temporal limitations into eternity, with the consequent contradictions that arise. For sense of individual being departs and "the 

autocrats Place and Time" are dominant. "Monos and
Una" was one of the preliminary steps to "Eureka."23

The cosmic cycle which Poe more clearly described in 1848 is briefly, though nonetheless completely, presented through the dialogue of Monos and Una. It is possible to view this colloquy as Poe's conscious effort to articulate the concepts which were taking form in his imagination.

E. H. Davidson writes of his purpose in this work:

Poe's apparent purpose in the tale was to offer a rational account of the passage of the human consciousness from life through death to the life-beyonddeath on the other side where occurs a final "merging" into "Love" or the harmonious principle uniting all things in the mind of God or the One. Individual existence is...returned to the primal order, the absolute focus from which the dispersive function had originally begun in the origin of time itself and of all matter. 24

By this time it appears that Poe had determined the process by which he would ultimately arrive at his cosmological conclusions in Eureka. It was a combination of observation, analysis, and intuition; the latter he had already indicated as the superior faculty, since it is "the divine mind itself acting immediately upon its creatures." The nature of intuition is explored further in "Mesmeric Revelation," published in the Columbian Magazine in August, 1844.

${ }^{23}$ A. Quinn, p. 325. See also Robert D. Jacobs, "Poe's Earthly Paradise," American Quarterly, XII (Fall, 1960) 404-413.

Poe, A Gritical Study, p. 133. 
In this work the state in which the intuitive faculty functions best is described as a death-like condition:

the phenomena resemble very closely those of death... while in this state, the person so impressed employs only with effort, and then feebly, the external organs of sense, yet perceives, with keenly refined perception, and through channels supposed unknown, matters beyond the scope of the physical organs; that, moreover, his intellectual faculties are wonderfully exalted and invigorated. 25

This description of the state in which man is capable of arriving at higher truths closely parallels the description of Dupin in the process of exercising his "peculiar analytic ability" and that of earlier Poe characters as they symbolically approached ultimate truth at the end of such tales as "Metzengerstein," "MS. Found in a Bottle," and The Narrative of Arthur Gordon Pym. In "Mesmeric Revelation" Vankirk, as Poe's spokesman, has revealed to him the state of God's existence:

He is not spirit, for he exists. Nor is he matter, as you understand it. But there are gradations of matter of which man knows nothing; the grosser impelling the finer, the finer pervading the grosser.... These gradations of matter increase in rarity or fineness, until we arrive at a matter unparticled-- without particles-indivisible-- one; and here the Taw of impulsion and permeation is modified. The ultimate or unparticled matter not only permeates all things, but impels all things; and thus is all things within itself. This matter is God...

${ }^{25} \mathrm{~V}$, p. 241. For a discussion of mesmerism in Poe's works, see Sidney E. Lind, "Poe and Mesmerism," PMIA, IXII $(1947), 1077-1094$. 
God, with all the powers attributed to spirit, is but the perfection of matter. ( $V, 245-246,248)$

Arthur H. Quinn has written of this "revelation": "Poe was ahead of his time, as usual, in his conception of this relation between God and man...he rejected the idea of the absorption of the individual in God... and assumes the validity of Mesmerism to ascertain the truth of immortality...it is a prelude to Eureka." 26

That Poe was uncertain of and possibly even apologetic for his views seems evident in the concluding sentence of "Mesmeric Revelation": "Had the sleep-walker, indeed, during the latter portion of his discourse, been addressing me from out the region of the shadows?t (V, 254). Despite this apparent attempt to bring the work back into the realm of fiction and remove it from the possibility of being interpreted as a philosophical discourse, Poe was still very much concerned with the originality and validity of his ideas. In a letter, dated January 4, 1845, to George Bush, Professor of Hebrew Language and Literature at New York University, he expresses this concern:

You will, of course, understand that the article is purely a fiction;--but I have embodied in it some thoughts which are original with myself \& I am exceedingly anxious to learn if they have claim to absolute originality, and also how far they will strike you as

26. Quinn, pp. 391-392, 419. 
well based. If you will be so kind as to look over the paper and give me, in 2 brief your opinion, I will

The ideas expressed in the fictional context of "Mesmeric Revelation" were presented more directly as Poe"s own metaphysical conclusions in that same year in a letter to James R. Lowell:

I have no belief in spirituality. I think the word a mere word. No one has really a conception of spirit. We cannot imagine what is not. We deceive ourselves by the idea of infinitely rarefied matter. Matter escapes the senses by degrees--a stone--a metal--a liquid-- the atmosphere--a gas-- the luminiferous ether. Beyond this there are other modifications more rare. But to all we attach the notion of a constitution of particles--atomic composition. For this reason only, we think spirit different; for spirit, we say is unparticled, and therefore is not matter. But it is clear that if we proceed sufficiently far in our ideas of rarefaction, we shall arrive at a point where the particles coelesce; for, although the particles be infinite, the infinity of littleness in the spaces between them, is an absurdity.--The unparticled matter, permeating \& impelling, all things, is God. Its activity is the thought of God--which creates. Man, and other thinking beings, are individualizations of the unparticled matter. Man exists as a "person," by being clothed with matter (the unparticled matter) which individualizes him. Thus habited, his life is rudimental, What we call "death" is the painful metamorphosis. 28

Although the full expression of Poe's Cosmic Myth was still thoo years away from this 1845 letter, it seems evident that many of his final conclusions had crystallized by this time. He had repeatedly treated the subject of complete catastrophic destruction, beginning with individuals, 
and progressing to families, mankind and the universe. He had treated the phenomenon of rebirth, following this destruction, and had made reference to his adherence, in part, to Laplace's theory of nebular cosmogony as the basis for understanding the cosmic cycle. He had drawn conclusions on the existence of God and the relativity of matter, and finally, he had determined the process through which he would understand and articulate his theories to be a combination of scientific investigation and intuition. What remained necessary, though, was some catalytic force which would at once lend some scientific credibility to the se theories and give him confidence in their expression.

This catalytic force seems to have taken the form of Alexander Von Humboldt's Gosmos: A Sketch of a Physical Description of the Universe, first published in 1845.29 Aside from the obvious scientific knowledge of the universe he acquired from this work, Poe must have been greatly impressed by Humboldt's approach to his discoveries, as stated in the first volume of Cosmos:

We would here remark that the abuse of thought, and the false track it too often pursues, ought not to sanction an opinion derogatory to intellect, which would imply that the domain of mind is essentially a world of vague fantastic illusions, and that the treasures accumulated by laborious observations in philosophy are powers hostile to its own empire. It does not become the spirit which characterizes the

${ }^{29}$ Poe dedicated Eureka to Humboldt and praised his approach in Cosmos. 
present age distmustfully to reject every generalization of views and every attempt to examine into the nature of things by the process of reason and induction. It would be a denial of the dignity of human nature and the relative importance of the faculties with which we are endowed, were we to condemn at one time austere reason engaged in investigating causes and their mutual connections, and at another that exercise of the imagination which prompts and excites discoveries by its creative powers. 30

Among others who influenced Poe, were Kepler and Laplace, their influence due as much to their approach as to their ideas. ${ }^{31}$ What seems to have impressed Poe about these two men, as he later reveals in Eureka, was their instinctual ability to arrive at truth, an ability he would exercise in his own discussion of the universe.

${ }^{30}$ (London, 1847), I, p. 78.

${ }^{31}$ For a brief discussion of the influence on Poe by earlier men of science, see Davidson, Poe, A Critical Study, pp. 131-132. See also his list of scientific works probably used by Poe as references, pp, 284-285. 


\section{EUREKA: THE DREAMER'S BOOK OF TRUTHS}

on February 3, 1848, Poe delivered a lecture on the cosmogony of the universe to an audience of about sixty people in the New York Society Library. Titled Eureka, the presentation lasted two and one-half hours and was, in part, Poe's attempt to raise funds for the publication of a magazine to be called The Stylus, which he hoped would re-establish him in the literary world. I In the summer of that same year, the work was published by G. P. Putnam as Eureka, A Prose Poem and was dedicated to Alexander von Humboldt. In his preface to what he chose to call a poem, but which, in fact, appeared more to be a lengthy and complex scientific essay, Poe characterized both his book and the audience for which it was intended:

To the few who love me and whom I love--to those who feel rather than to those who think-- to the dreamers and those who put faith in dreams as the only realities--I offer this Book of Truths, not in its character of Truth-Teller, but for the Beauty that abounds in its Truth: constituting it true. To these I present the composition as an Art-Product alone:-let us say as a Romance; or, if I be not urging too lofty a claim, as a Poem. 2

$\mathrm{I}_{\text {See }}$ "Preface" to this paper and Woodberry, II, pp. 237-239 for further discussion of Poe's practical reasons for the New York lecture.

${ }^{2}$ XVI, p. 183. All quotations from Eureka hereafter will be followed by parenthetical indications of page numbers only. 
Such is this last long work of Poe's, a "Book of Truths," written for dreamers by a life-long dreamer; an intuitive artist-scientist, who found in this culmination of years of scientific investigation and artistic exploration a total vision of man's destiny in the cosmic cycle of "alternate dissolution and rejuvenescence ad infinitum" $(x, 160)$. Paul Valery writes of the interesting blending of science and art in Eureka:

The reader of Eureka will see how Poe has extended the application both of the nebular hypothesis and the law of gravity. On these mathematical foundations he has built an abstract poem, one of the rare modern examples of a total explanation of the material and spiritual universe, a cosmogony. It belongs to a department of literature remarkable for its persistence and astonishing in its variety; cosmogony is one of the oldest of all literary forms. ${ }^{3}$

Poe had written in the preface to his prose poem that the beauty of Eureka "abounds in its truth," and, in this sense, its poetry lies in the beauty of its ideas, rather than its form. Edward Wagenknecht views Poe's preface as a

3"Poe's 'Eureka'," The Recognition of Edgar Allan Poe, ed. Eric Carlson (Ann Árbor, Michigan, 1966), p. 110. First published as the preface to Baudelaire's translation of Eureka in 1921. For a discussion of Poe's influence on Valery, see T. S. Eliot, "From Poe to Valery," pp. 205-219 in the volume cited above. Vincent Buranelli has a qualified view of Poe as a scientist: "It is real science, and Poe may. be called a 'scientist' if the term is restricted to one who, without being a laboratory experimentalist, read a mass of scientific literature, meditated at length about the import of the latest theories, and then formulated his own systen." Edgar Allan Poe (New York, 1961), p. 51. See also Stephen L. Mooney, "Poe's Gothic Wasteland," The Recognition of Edgar Allan Poe, (Ann Arbor, Michigan, 1966), pp. 278-297. 
testament to his faith in poetry: "When he wrote these words, poe was not disparaging Eureka. He was testifying to his faith in Poetry, as the highest truth and the highest means of insight into truth....." 4

The significance of Eureka in this paper rests primarily in the evidence that the work represents the culmination of over twenty years of Poe's speculation on the origin, nature and destiny of man and his universe. The many fragments of his total concepts, recognizable in the earlier works from 1827 to 1848 , appear to constitute an evolutionary process which resulted in an expression of his crystallized vision in Eureka. Haldeen Braddy writes of the relationship of Poe's early works and the 1848 essay" "It is clear that the philosophy incorporated in Eureka was the oulmination and efflorescence of much of his earlier thinking. Many of his profoundest thoughts are foreshadowed in the ideas appearing not only in the tales but also in the essays and especially in the poems. ${ }^{5}$

\section{${ }^{4}$ Edgar Allan Poe, The Man Behind the Legend (New York, 1963), p. 219 .}

\section{5} Eureka as a summary of many of Poe's earlier ideas and approaches: "The poems were assumptions that mind and reality coexisted in some total design; the moral tales sought ways of measuring man against that rationale of the schematic universe; the ratiocinative stories destroyed the normative world and opened the suddenly revealed 'ideal' in the crime and in its solution. In Eureka Poe would summarize and try to make coherent these approaches to a logical science and philosophy." Poe, A Critical Study, p. 222. For further discussions see L. J. Lafleur, "E. A. Poe as Philosopher," Cersonalist, XXII (October, 1941), $401-405$ and P. P. Wiener, Poe's Logic and Me taphysic," Personalist, XIV (October, 1933), 268-274. 
Although an understanding of all of the specific scientific conclusions expressed in Eureka is not necessary to appreciate the position of this work in the evolution of Poe's Cosmic Myth, and a discussion of that sort would be out of place here, it is nevertheless important to understand at least the general conclusions of the book and Poe's method of arriving at those conclusions. Several weeks after the New York lecture, Poe wrote to George W. Eveleth and included in his letter an abstract of Eureka:

The General Proposition is this:--Because Nothing was, therefore All Things are.

1--An inspection of the universality of Gravitation--i.e., of the fact that each particle tends, not to any one common point, but to every other particle--suggests perfect totality, or absolute unity, as the source of the phenomenon.

$2--$ Gravity is but the mode in which is manifested the tendency of all things to return into their original unity; is but the reaction of the first Divine Act.

3--The law regulating the return--i.e., the law of Gravitation is but a necessary result of the necessary \& sole possible mode of equable irradiation of matter through space:--this equable irradiation is necessary as a basis for the Nebular Theory of Laplace. 4--The Universe of Stars (contradistinguished from the Universe of Space) is limited.

5--Mind is cognizant of Matter only through its two properties, attraction and repulsion: therefore Matter is only attraction \& repulsion:...

6--Matter, springing from Unity, sprang from Nothingress:- $i$.e., was created.

7--All will return to Nothingness, in returning to Unity.... What I have propounded will (in good time) revolutionize the world of Physical \& Me taphysical Science. I say this calmly--but I say it.

60strom, II, pp. 361-362. Woodberry is extremely critical of Poe's presumption in Eureka and writes that "Poe's 
Poe begins his "essay on the Material and Spiritual Universe" with all the brashness of a young scientist about to destroy formerly held truths with his startling revelations. In one sweeping sentence he summarizes his objectives: "I design to speak of the Physical, Metaphysical and thematical--of the Material and Spiritual Universe:--of Hssence, its Origin, its Creation, its Present Condition and its Destiny" (p. 185). He then states his "general proposition" as: "In the Original Unity of the First Thing Mes the Secondary Cause of All Things, with the Germ of their Inevitable Annihilation" (pp. 185-186). Davidson writes of Poe's theory of unity and his early works: "In Eureka...Poe made a final and thorough investigation of the principles of unity to diffusion and back to unity again,

theory belongs to the infancy of speculation, to the period before physics was separated from ontology...." The life of E. A. Poe, II, p. 247. There are many discussions of the relative scientific value of Eureka. For arguments on both sides of the issue, see Clayton Hoagland, "The Universe of pareka: A Comparison of the theories of Eddington and Poe," euthern Literary Messenger, I (May, 1939), 307-313; George brdstedt, "Poe and Einstein," Open Court, XIIV (1930), 173180 ; Frederick Bond, "Poe as Evolutionist," Popular Science Monthly, LXXI (1907), 267-274; A. H. Quinn, Poe, A Critical Biography, pp. 541-557; C. R. Wylie, "Ma thematical Allusions in Poe," Scientific Monthly (September, 1946), 227-235; E. A. Molina, "Mathematical Allusions in Poe," Scientific Monthly (January, 1947), 89; A. R. Wallace, Edgar Allan Poe (New York, n.d.) A séries of Seventeen Letters concerning Poe's Scientific Erudition in Eureka; W. H. Broune, "Poe's Eureka and Recent Scientific Speculations, is New Eclectic Magazine (August, 1869); and S. P. Cutler, "Poe's Eureka Reconsidered," Eclectic Magazine (November, 1869). 
principles which undertay the theory and practice of the horror poem and tale in his earlier years." 7

After dismissing the deductive reasoning of Aristotle and the inductive reasoning of Bacon as methods too slow to mprehend the universe, he praises the remarkable capacity to guess on the part of Laplace and Kepler, and states that even Newton's discoveries are based on the latter's guesses. Three years before Eureka, Poe had written in the Opal:

That the imagination has not been unjustly ranked as supreme among the mental faculties, appears from the intense consciousness, on the part of the imaginative man, that the faculty in question brings his soul often to a glimpse of things supernal and eternal-- to the very verge of the great secrets.... Some of the most profound knowledge--perhaps all very profound knowledge--has originated from a highly stimulated imagination. Great intellects guess well. The laws of Kepler were, professedly, guesses.8

7Poe, A Critical Study, pp. 134-135. Margaret Alterton agrees with Davidson: "...cosmic unity is Poe's solution of the problem of life and death which had always engaged his mind and heart." "Introduction," E. A. Poe, Representative Selections, p. xlii.

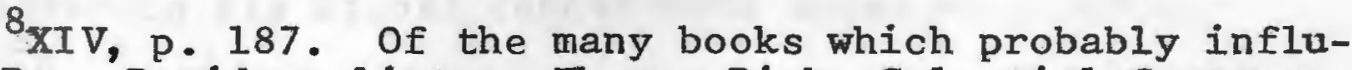
enced Poe, Davidson lists: Thomas Dick, Gelestial Scenery (New York, 1838) and The Sidereal Heavens and Other subjects Connected wi th Astronomy (New York, 1840); J. F. W. HerscheI, A Treatíse on Astronomy (Philadelphia, 1834); Pierre Simon, Marquis de Laplace, The System of the World, tr. and ed. H. H. Harte (London, 1830); J. P. Nichol, Views of the Architecture of the Heavens (Iondon, 1838) and The Phenomena and Order of the Solar System (New York, 1842). Poe, A Critical Study, pp. 284-285. Carol Maddison adds: William Whervell's Astronomy and General Physics Considered with reference to Natural Theology; Chambers "Vestiges of Creation, and Kants" Universal Natural History and Theory of the Heavens. "Poe's Eureka," Texas Studies in Literature and Language, II (Spring, 1960), 350-367. See also, Killis Campbeil, "Poe's Reading," University of Texas Studies in English, V, 166-196. 
Poe approaches the discussion of the universe by beginning with infinity, stating that although the word is beyond comprehension, he will use it to mean "the "utmost conceivable expanse" of space--a shadowy and fluctuating domain, now shrinking, now swelling, with the vacillating energies of the imagination" (p. 204). In using the term "universe," he makes the distinction between the common usage--referring to the universe of stars, and his--referring to the universe of space. He defines the latter as: sphere of which the center is everywhere, and the circumEerence nowhere" (p. 205), a definition adopted from Pascal. Arriving then at God, Poe makes what he terms his first and only "assumption," based on an intuition, which he describes as "the conviction arising from those deductions and inductions of which the processes are so shadowy as to escape our consciousness, elude our reason, or defy our capacity for expression" (p. 206). The assumption is that the original creation of the primordial particle "could have been nothing but Matter in its utmost conceivable state of... Simplicity...." (p. 206). When we consider matter in a state of extreme simplicity, he says, our reason "flies at once" to the thought of a single particle, "without form and void... unique, individual, undivided" (p. 206). He clarifies this assumption by explaining:

Oneness, then, is all that I prediaate of the originally created Matter; but I propose to show that this Oneness is a principle abundantly sufficient to account for the constitution, the existing phaenomena 
and the plainly inevitable annihilation of at least the material Universe.

The willing into being the primordial particle, has completed the act, or more properly the conception, of Creation. We now proceed to the ultimate purpose for which we are to suppose the Particle created--that is to say, the ultimate purpose so far as our considerations yet enable us to see it--the constitution of the Universe from it, the Particle. (pp. 206-297)

From this particle in its state of "Oneness" and the exercise of God's will, Poe supposes "to be irradiated pherically--in all directions--to immeasurable but still to definite distances in the previously vacant space--a certain inexpressibly great yet limited number of unimaginably yet not infinitely minute atoms" (pp. 207-208). Since the "original and therefore normal" condition of these atoms is Unity, he concludes that even in the diffusion they "contain the seeds" of returning to that original state "at that ultimate epoch" (p. 211). Out of the original irradiation has been created the forces of "attraction" and "repulsion" between the atoms, which Poe defines as the only characteristics of matter: "...matter exists only as attraction and repulsion...they are matter" $(p, 214)$. His discussion of attraction, a term which he substitutes for gravity, takes on a poetic quality to clarify the meaning and emphasize the importance of that force:

Every atom, of every body, attracts every other atom... sympathizes with the most delicate movements... of every other atom... If I venture to displace, by... even the billionth part of an inch, the microscopical speck of dust which lies now upon the point of my finger, what is the character of that act upon which I 
have adventured? I have done a deed which shakes the Moon in her path, which causes the Sun to be no longer the Sun, and which alters forever the destiny of the multitudinous myriads of stars....

These ideas--conceptions such as these--

unthought-like thoughts--soul-reveries rather than conclusions or even considerations of the intellect:-ideas, I repeat, such as these, are such as we can alone hope profitably to entertain in any effort at grasping the great principle, Attraction. (pp. 217219)

After discussing the irradiation of matter equably throughout the orginally void universe, Poe then proceeds to use Laplace's Nebular Hypothesis in describing the creation of our Solar System as one of the agglomerations of matter, which must be finite "since there could be absolutely no point, in all that background at which would not exist a star," if it were infinite (pp. 273 274). He describes the original state of our Solar system as an immensely hot globe, the circumference of which was roughly equal to the present orbit of Neptune. As this globe rotated, its outer crust cooled, became denser than the body, separated, and was spun off, creating a ring around the now smaller globe. As the ring cooled, it became even denser, and eventually, as a result of the natural attraction of $i$ ts atoms and its revolving motion, became an orbiting globe or planet. This process was repeated until the present Solar System was formed, and according to Poe, is still functioning, since the entire universe is in the process of perfection. This perfection is part of the order and design of the universe and is achieved through the process of adaptation: 
As density proceeds--as the divine intentions are accomplished--as less and still less remains to be accomplished--so--in the same ratio--should we expect to find an acceleration of the End:--and thus the philosophical mind will easily comprehend that the Divine designs in constituting the stars, advance mathematically to their fulfilment....

Not only is this Divine adaptation, however, mathematically accurate, but there is that about it which stamps it as divine, in distinction from that which is merely the work of human constructiveness. I allude to the complete mutuality of adaptation.... In Divine constructions the object is either design or object as we choose to regard it--and we may take at any time a cause for an effect, or the converse-so that we can never absolutely decide which is which. (pp. 291-292)

Once the force of the original action, irradiation or diffusion, begins to diminish, the reaction, the force of gravity or attraction, will become greater than that of repulsion, and the atoms of the universe will return to their original state of Oneness. At the point when attraction becomes the greater force, matter will become more sentient as it approaches homogeneity and dissolves into the thought of God:

The equilibrium between the...forces...being...destroyed...there must occur, at once, a chaotic or seemingly chaotic precipitation of the moons upon the planets, of the planets upon the suns, and of the suns upon the nuclei.... While undergoing consolidation, the clusters themselves, with a speed prodigiously accumulative, have been rushing towards their own general centre--and now, with a thousand-fold electric velocity, commensurate only with their material grandeur and with the spiritual passion of their appetite for oneness, the majestic remnants of the tribe of stars clash, at length, into a common embrace....through the agency of Matter, and by dint of its heterogeneity... particular masses of Matter become animate--sensitive-and in the ratio of their heterogeneity;--some reaching a degree of sensitiveness involving what we call Thought and thus attaining Conscious Intelligence. (pp. 307-309) 
Matter is a means, not an end, Poe writes, and its purpose is understood in its diffusion as the created universe. When matter returns to its original unity, its purpose ceases, and it no longer exists. He writes: "Let us endeavor to understand that God would remain all in all" (p. 309). But Poe does not leave us there. Inthe cyclic action he had conceived, he concludes that the process may be repeated, over and over:

Guiding our imaginations by that omiprevalent law of laws, the law of periodicity, are we not... justified in entertaining a belief...that the processes....will be renewed forever, and forever, and forever; a novel Universe swelling into existence, and then subsiding into nothingness, at every throb of the Heart Divine? And now--this Heart Divine--what is it? It is our own. (p. 311)

The conclusion to Eureka, while it attempts to comfort us in an awareness of the present, is startling in its vision of the future:

Think that the sense of individual identity will be gradually merged in the general consciousness--that Man, for example, ceasing imperceptibly to feel himself Man, will at length attain that awfully triumphant epoch when he shall recognize his existence as that of Jehovah. In the meantime bear in mind that all is Life--Life--Life within Life--the less within the greater, and all within the Spirit Divine. (pp. 314-315)

Poe's journey has thus found its end in the awareness that man's destiny is, in fact, the destiny of God and that man's immortality rests "within the Spirit Divine." Allan Tate writes of Poe's conclusion: 
Thus, says Poe at the end of Eureka, not only is every man his own God, every man is God: every man the non-spatial center into which the universe, by a reverse motion of the atoms, will contract, as into its annihilation. God destroys himself in the eventual recovery of his unity. Unity equals zero. If Poe must at last "yield himself unto Death utterly," there is a lurid sublimity in the spectacle of his taking God along with him into a grave which is not smaller than the universe. 9

If it is possible to view the ultimate expression of Poe's Cosmic Myth in Eureka as having artistically evolved through the themes of the poetry, tales and essays from 1827-1848--and that appears to be a reasonably safe assumption--then the possibility also exists that, using the general conclusions of Eureka as a basis, a better understanding of those earlier more literary works may be arrived at. The conflicts in "Tamerlane" between the intellect and spirit and between reality and illusion take on a deeper meaning when viewed as the earliest thematic manifestations of Poe's intellectual struggling towards an awareness of the meaning of existence. By 1848 intellect and spirit become reason and intuition, while the conflict between reality and illusion is resolved in the intuitive vision of the ultimate unity of all matter.

The characteristics and consequences of the destruction which occurs on various levels and to varying degrees in such poems as "Al Aaraaf" and "The City in the Sea" and

9 "The Angelic Imagination," The Forlorn Demon (Chicago, 1953), p. 76 . 
tales like "MS. Found in a Bottle," "The Fall of the House of Usher," Pym and the colloquies foreshadow those of the universal collapse in Eureka. The ratiocinative tales also take on a clearer meaning when viewed as representations of Poe's method of arriving at truth: a combination of reason and intuition, very similar to his approach in Eureka. Most important is Poe's great concern for the concept of unity, expressed in his artistic as well as philosophical theories. Carol Maddison writes of the origin of Poe's theory of unity:

Poe...derived his hypothesis of the perfect unity of the universe from his aesthetic theory, under the stimulation of current scientific and philosophic thought.... The details he used to fill his worldpicture were derived from the discoveries of modern science. But Eureka was Poe's last and most impressive imaginative work. 10

In a letter to Mrs. Clemm, dated July 7, 1849, Poe wrote: "I have no desire to live since I have done 'Eureka'."11 It appears that he had poured himself, body and soul, into the writing of Eureka and that in it he was finally able to draw together the various fragments of his earlier thinking into a final, all-inclusive statement. W. H. Auden writes of the merging of Poe's passions in

\section{Eureka:}

10 "Poe's Eureka," p. 367.

${ }^{11}$ Ostrom, II, p. 452. For Mrs. Clemm's deseription of Poe during the writing of Eureka, see Israfel, p. 586. See al so Carro11 Laverty, "Poe in 1847, XX (May, 1948), 163-168. 
...it combines in one work nearly all of Poe's characteristic obsessions: the passion for merging in union with the one which is at the root of tales like "Ligeia," the passion for logic which dominates the detective and cryptographic studies, the passion for a final explanation and reconciliation which informs the melancholy of much of his verse--all are brought together in this poem of which the prose is as lucid, as untheatrical, as the best of his critical prose.12

From the earlieststirrings of his visionary tendencies exhibited in "Tamerlane," into the imaginary explorations on the nature of human existence in the symbolic poems and tales, through his growing awareness of the faculties of the human mind, to the final vision in Eureka, Poe had taken his personal intellectual and spiritual journey from darkness to light. He encountered at the end of his voyage the blinding whiteness which Pym had experienced, but, unlike Pym, he returned long enough to share the knowledge he acquired with those who loved him and those whom he loved. Poe's imagination and dreams provided for him the vision for which the laws of science were inadequate. He was, as Robert Hamilton writes, "a lonely visionary peering in to the night, 'dreaming dreams no mortals dared to dream before "13 out of those many years of soul-reveries and nightmares and the relentless searching for the meaning of existence, had evolved a Cosmic Myth, the vision of which was so complete, Poe could shout, "Eureka! I have found it?"

\footnotetext{
12"Introduction," Poe, Selected Prose and Poetry (New York, 1964), p. xi.

13 "Poe and the Imagination," Quarterly Review, CXXVII (October, 1950), 525. Marie Bonaparte 1nterprets Poe's dreaming" in Euréka as "homo sexual phantasy." The Life and Works of E. A. Poe, p. 636 .
} 


\section{BIBLIOGRAPHY}

Abel, Darrell. "A Key to the House of Usher," University of Toronto Quarterly, XVIII (1949), 176-186.

Allen, Hervey. Israfel, The Life and Times of Edgar Allan Poe. New York, 1934.

Allen, Mozelle. "Poe's Debt to Voltaire," Texas Studies in English, XV (1925), 63-75.

Almy, R. F. "J. N. Reynolds: A Brief Biography with particular Reference to Poe and Symmes," The Colophon, New Series, II (winter, 1937), 227-245.

Alterton, Margaret. Origins of Poe's Critical Theory. New York, 1965.

Alterton, Margaret and Hardin Craig, eds. Edgar Allan Poe, Representative Selections. New York, 1962 .

Bailey, J. O. "Sources of Poe's Arthur Gordon Pym, 'Hans Pfaal, and other pieces," PMLA, LVII (June, 1942), 513-535.

House of Usher'?" American Literature, XXXV (January, 1964), 445-466.

Baker, H. T. "Coleridge's Influence on Poe's Poetry," Modern Language Notes, XXV (1910), 94-95.

Baldwin, C. S. "Poe's Invention of the Short Story," American Short Stories. New York, 1904, Pp. 15-22.

Beebe, Maurice. "The Fall of the House of Pyncheon," Nineteenth Century Fiction, XI (July, 1956), pp. 1-17.

"The Universe of Roderick Usher," Poe, A Collection of Critical Essays, ed. Robert Regan. Englewood Cliffs, New Jersey, 1967, pp. 121-133.

Beldon, H. M. "Poe's City in the Sea and Dante's Gity of Dis," American Literature, VI (November, 1935), 332-334.

Benson, A. B. "Sources of Poe's 'A Descent into the Maelstrom'" Journal of English and Germanic Philology;

XLVI (July, 1947), 298-301. 
Benzanson, W. W. "The Troubled Sleep of Arthur Gordon Pym," Essays in Literary History Presented to J. Milton French. New Brunswick, N. J., 1960, pp. 149-175. Birkhead, Edith. The Tale of Terror. London, 1921. Bonaparte, Marie. The Life and Works of Edgar Allan Poe, tr. John Rodker. London, 1949.

Bond, Frederick. "Poe as Evolutionist," Popular Science Monthly, LXXI (1907), 267-274.

Braddy, Haldeen. Glorious Incense. Port Washington, New York, 1953.

Broune, W. H. "Poe's Eureka and Recent Scientific Speculations," New Eclectic Magazine (August, 1869).

Buranelli, Vincent. Edgar Allan Poe. New York, 1961.

Gairns, W. B. "Some Notes on Poe's 'Al Aaraaf'," Modern Philology, (May, 1915), 35-44.

Campbell, Killis. The Mind of Poe and other Studies. New York, 1933.

1917.

The Poems of Edgar Allan Poe. Boston,

"Poe's Indebtedness to. Byron," Nation, IXXXVIII (1909), 248-249.

"Poe's Knowledge of the Bible," Studies in Philology, XXVII (1930), 546-552.

Carlson, Eric W., ed. Introduction to Poe, A Thematic Reader. Glenview, Illinois, 1967.

Coad, Oral s. "The Gothic Element in American Literature before 1835," Journal of English and Germanic Philology XXI V, 72-93.

Cowley, Malcolm. "Aidgarpo," New Republic, V (November, 1945), 607-610.

Cutler, S. P. "Poe's Eureka Reconsidered," New Eclectic Magazine (November, 1869).

Davidson, Edward H. Poe, A Critical Study. Cambridge, Mass., 1957.

- ed. Selected Writings of Edgar Allan

Poe. Cambridge, Mass., 1956. 
Eliot, Thomas Stearns. "From Poe to Valery," The Recognition of Edgar Allan Poe, ed. Eric Carlson. Ann Arbor, Michigan, 1966, pp. 205-219.

Fiedler, Leslie. "The Blackness of Darkness: The Negro and the Development of American Gothic," Images of the Negro in American Literature, eds. Seymour Gross and John Hardy. Chicago, 1966.

Forrest, W. M. Biblical Allusions in Poe. New York, 1928. Gargano, James $W$. "Poe's 'Ligeia': Dream and Destruction," College English, XXIII (February, 1962), 337-342.

College English, XXV (December, 1963), 177-181.

Hamilton, Robert. "Poe and the Imagination," Quarterly Review, CXXVII (October, 1950), 514-525.

Hoagland, Clayton. "The Universe of tureka: A Comparison of the theories of Eddington and Poe," Southern Literary Messenger, I (May, 1939), 307-313.

Humboldt, Alexander von. Cosmos: A Sketch of a Physical Des cription of the Universe. 10 vols. London, 1847.

Huntress, Keith. "Another Source for Poe's Pym," American Literature, XVI (March, 1944), 19-25.

Jacobs, Robert D. "Poe's Earthly Paradise," American Quarterly, XII (Fall, 1960), 404-413.

Kaplan, Sidney. "Introduction," The Narrative of Arthur Gordon Pym. New York, 1960 .

Kendall, Lyle. "The Vampire Motif in 'The Fall of the House of Usher"," College Engli sh, XXI V (March, 1963), 450453 .

Lafleur, L. J. "E. A. Poe as Philosopher," Personalist, XXII (Óctober, 1941), 401-405.

Laverty, Carroll. "Poe in 1847," American Literature, XX (May, 1948), 163-168.

Laverty, Carroll D. "Poe's Conception of Incident and Tone in the Tale," Modern Philology, XVI (1944), 228-240.

Lawrence, D. H. "Edgar Allan Poe," Studies in Classic American Literature. New York, 1953, pp. 73-92.

Levin, Harry. The Power of Blackness. New York, 1958. 
Lind, Sidney E. "Poe and Mesmerism," PMLA, LXII (1947), 1077-1094.

Maddison, Carol. "Poe's Eureka," Texas Studies in Literature and Language, II (Spring, 1960), 350-367.

Mabbott, Thomas 0. "The Letters from George W. Eveleth to Edgar Allan Poe," Bulletin of New York Public Library, XXVI (1922), 171-195.

Sewanee Review, XXXVI, 171-176.

Marks, A. H. "Two Rodericks and Two Worms: 'Egotism; Or, The Bosom Serpent'," PMLA, LXXIV (December, 1959), 607-612.

McKeithan, D. M. "Two Sources of Poe's 'Narrative of Arthur Gordon Pym'," Texas studies in English, XIII (July, 1933), 116-137.

Molina, E. A. "Mathematical Allusions in Poe," Scientific Monthly (January, 1947), 89.

Mooney, Stephen. "Poe's Gothic Wasteland," The Recognition of Edgar Allan Poe, ed. Eric W. Carlson. Ann Arbor, Michigan, 1966, Pp. 278-297.

More, P. E. "Origins of Hawthorne and Poe," Shelburne Essays, First Series. New York, 1904, PP. 51-70.

Nordstedt, George. "Poe and Einstein," Open Court, XIIV $(1930), 173-180$.

0'Donnell, Charles. "From Earth to Ether: Poe's Flight into Space," PMLA, IXXVII (March, 1962), PP. 85-91.

Olivero, Federico. "Symbolism in Poe's Poetry," Westminster Review, (1913), 201-207.

Ostrom, John Ward, ed. The Letters of Edgar Allan Poe. 2 vols. Cambridge, Mass., 1948.

Pettigrew, R. C. and M. M. "A Reply to Floyd Stovall's Interpretation of 'Al Aaraaf'," American Literature, VIII (1937), 439-445.

Poe, Edgar Allan. The Complete Works of Edgar Allan Poe. 17 vols., ed. James A. Harrison. New York, 1965. Mabbott. NeW York, 1941 .

Pound, Louise. "On Poe's 'The City in the Sea', "American Literature, VI (March, 1934), 22-27. 
"On Poe's 'The City in the Sea"

Again," American Literature, VIII (March, 1936), 70-71.

Quinn, Arthur Hobson. Edgar Allan Poe, A Critical Biography. New York, 1941.

Quinn, Patrick. The French Face of Edgar Allan Poe. Carbondale, Illinois, 1947.

Rein, D. M. Edgar Allan Poe, The Inner Pattern. New York, 1960 .

Rhea, Robert L. "Some Observations of Poe's Origins," Texas Studies in English, X (July, 1930), 135-146.

Robinson, E. Arthur. "Order and Sentience in "The Fall of the House of Usher'," PMLA, LXXVI (March, 1956), 68-81.

Schroeter, James. "A Misreading of Poe's 'Ligeia'," PMLA, LXXVI (Sep tember, 1961), 397-406.

Shockley, Martin S. "Timour the Tartar' and Poe's 'Tamerlane'," PMLA, LIX (December, 1941), 1103-1106.

Spitzer, Leo. "A Re-interpretation of 'The Fall of the House of Usher'," Comparative Literature, IV (January, 1937), 379-401.

Starke, Aubrey. "Poe's Friend Reynolds," American Literature, XI (May, 1939), 152-166.

Stovall, Floyd. "An Interpretation of Poe's 'Al Aaraaf'," University of Texas Studies in English, IX (1929), 106-133.

"Poe's Debt to Coleridge," University of Texas Studies in English, $x(1930), 70-127$.

Tate, Allen. "The Angelic Imagination: Poe as God," The Forlorn Demon. Chicago, 1953, pp. 56-78.

"Three Commentaries: Poe, James, and Joyce," Sewanee Review, LVII (January-March, 1950), $1-4$.

Thompson, G. R. "Unity, Death and Nothingness--Poe's 'Romantic Skepticism'," PMLA, IXXXV (March, 1970), 297-300.

Valery, Paul. "On Poe's "Eureka'," The Recognition of Edgar Allan Poe, ed. Eric Carlson. Ann Arbor, Mifchigan, $1966, \mathrm{pp} .103-110$. 
Wagenknecht, Edward. Edgar Allan Poe, The Man Behind the Legend. New York, 1963.

Walcutt, C. C. "The Logic of Poe," College English, II (February, 1941), 438-444.

Wallace, Alfred R. Edgar Allan Poe. New York, n.d.

Warfel, H. R. "Poe's Dr. Percival: A Note on 'The Fall of the House of Usher", Modern Language Notes, LIV

(February, 1939), 129-131.

Wiener, P. P. "Poe's Logic and Metaphysic," Personalist, XIV (October, 1933), 268-274.

Wilbur, Richard. "The House of Poe," Poe, A Collection of Critical Essays, ed. Robert Regan. New Jersey, 1967, pp. 98-120.

Wilson, James S. "The Letters of Edgar Allan Poe to George W. Eveleth," Alumni Bulletin, University of Virginia, XVII (January, 1924), 34-39.

Wilt, Napier. "Poe's Attitude toward his Tales," Modern Philology, XXV (1927), 101-105.

Winters, Ivor. "E. A. Poe: A Crisis in the History of American Obscurantism," American Literature, VIII (January, 1937), 379-401.

Winwar, Frances. The Haunted Palace, A Life of Edgar Allan Poe. New York, 1959 .

Woodberry, George E. The Life of Edgar Allan Poe. 2 vols. Boston, 1909.

Wylie, C. R. "Mathematical Allusions in Poe," Scientific Monthly (September, 1946), 227-235. 